\title{
Summer bloom of Vulcanodinium rugosum in Cienfuegos Bay (Cuba) associated to dermatitis in swimmers
}

\author{
Moreira-González Angel R. 1,2, Comas-González Augusto 1, Valle-Pombrol Aimee 1, \\ Seisdedo-Losa Mabel ${ }^{1}$, Hernández-Leyva Olidia ${ }^{3}$, Fernandes Luciano F. ${ }^{4}$, Chomérat Nicolas ${ }^{5}$, \\ Bilien Gwenael ${ }^{5}$, Hervé Fabienne ${ }^{6}$, Rovillon Georges-Augustin ${ }^{6}$, Hess Philipp ${ }^{6}$, \\ Alonso-Hernández Carlos M. ${ }^{1}$, Mafra Luiz L. ${ }^{2,}{ }^{*}$
}

\footnotetext{
${ }^{1}$ Centro de Estudios Ambientales de Cienfuegos (CEAC), AP. 5, Ciudad Nuclear, CP 59350,

Cienfuegos, Cuba

${ }^{2}$ Centro de Estudos do Mar, Universidade Federal do Paraná, P.O. Box 61, Av. Beira Mar, s/n, Pontal do Paraná, Paraná 83255-976, Brazil

${ }^{3}$ Centro Provincial de Higiene, Epidemiología y Microbiología de Cienfuegos, 13 Calzada de Máximo

Gómez, Cienfuegos 55100, Cuba

${ }^{4}$ Departamento de Botânica, Universidade Federal do Paraná, Centro Politécnico, R. Elétrica, 540,

Curitiba, Paraná 82590-300, Brazil

5 IFREMER, Laboratory of Environment and Resources Western Brittany, Coastal Research Unit, Quai de la Croix, 29900 Concarneau Cedex, France

${ }^{6}$ IFREMER, DYNECO, Laboratoire Phycotoxines, Rue de l'Île d'Yeu, 44311 Nantes Cedex 03, France

* Corresponding author : Luiz L. Mafra, email address : luiz.mafra@ufpr.br

angel@gestion.ceac.cu ; augusto@gestion.ceac.cu ; aimee@gestion.ceac.cu ;

mabel@gestion.ceac.cu ; olidiah@jagua.cfg.sld.cu ; lff@ufpr.br ; nicolas.chomerat@ifremer.fr ;

gwenael.bilien@ifremer.fr ; fabienne.herve@ifremer.fr ; georges.augustin.rovillon@ifremer.fr ;

philipp.hess@ifremer.fr ; c.m.alonso-hernandez@iaea.org ;
}

\begin{abstract}
The marine dinoflagellate Vulcanodinium rugosum produces powerful paralyzing and cytotoxic compounds named pinnatoxins (PnTX) and portimines. Even though, no related human intoxication episodes following direct exposure in seawater or the ingestion of contaminated seafood have been documented so far. This study aimed at investigating a dinoflagellate bloom linked to acute dermatitis cases in two recreational beaches in Cienfuegos Bay, Cuba. We used epidemiological and clinical data from 60 dermatitis cases consisting of individuals in close contact with the bloom. Seawater physicalchemical properties were described, and the microorganism causing the bloom was identified by means of light and scanning electron microscopy. Morphological identification was confirmed genetically by sequencing the internal transcribed spacers ITS1 and ITS2, and the 5.8S rDNA region. Toxic compounds were identified from a bloom extract using liquid chromatography (LC) coupled to high-resolution mass spectrometry (HRMS), and their concentrations were estimated based on low-resolution tandem mass spectrometry (LC-MS/MS). Sixty people who had prolonged contact with the dinoflagellate bloom suffered acute dermal irritation. Most patients (79.2\%) were children and had to be treated with antibiotics; some required $>5$-day hospitalization. Combined morphological and genetic characters indicated V. rugosum as the causative agent of the bloom. rDNA sequences of the V. rugosum genotype found in the bloom
\end{abstract}


aligned with others from Asia, including material found in the ballast tank of a ship in Florida. The predominant toxins in the bloom were portimine, PnTX-F and PnTX-E, similar to strains originating from the Pacific Ocean. This bloom was associated with unusual weather conditions such as frequent and prolonged droughts. Our findings indicate a close link between the V. rugosum bloom and a dermatitis outbreak among swimmers in Cienfuegos Bay. Phylogenetic evidence suggests a recent introduction of V. rugosum from the Pacific Ocean into Caribbean waters, possibly via ballast water.

\section{Graphical abstract}

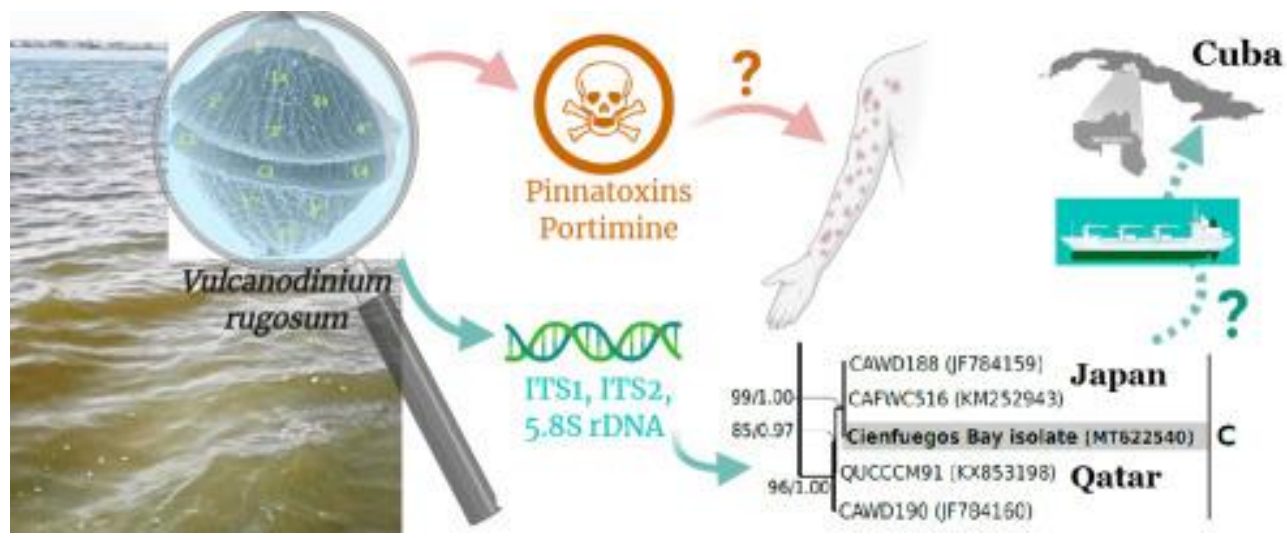

\section{Highlights}

First report of a Vulcanodinium rugosum bloom affecting human health $\$$ Sixty people, mostly children, developed acute skin irritation upon direct exposure. Bloom contained pinnatoxins and portimine, potential causative factors of dermatitis. Phylogenetics suggest recent introduction from the Pacific Ocean via ballast water. Bloom associated with unusual droughts and exceptionally high temperatures

Keywords : harmful algal bloom, human health, skin irritation, emergent toxin, toxic dinoflagellate, microbial biogeography 


\section{Introduction}

Marine microalgae, both benthic and planktonic, play a vital role in the marine food webs. By converting carbon dioxide and water into organic matter through photosynthesis, these organisms provide food and energy to most consumers in the 
marine food webs. Events of microalgal blooms are natural phenomena sustaining part of the world's oceans productivity. However, not all microalgal proliferations are beneficial; some of them can pose negative threats to the environment and human societies (e.g. public health, aquaculture, recreational activities, etc.), with associated economical losses (Anderson et al., 2000, 2015; Berdalet et al., 2016). These latter proliferations are named Harmful Algal Blooms (HABs) in association to the noxious effects they cause, regardless of the cell abundance attained in a given occasion. Among the HAB-forming microalgae, tens of species - mostly dinntla rellates - may produce powerful toxins capable of causing severe human hea' ${ }^{\prime}{ }_{1}$ roblems (Hallegraeff, 2003; Lassus et al., 2016).

Ingestion of shellfish and fish contamirater with algal toxins may lead to outbreaks of different human poisoning sy`a. im «s, including the Amnesic, Diarrhetic, Neurotoxic and Paralytic Shellfish I is ,nings, Azaspiracid Poisoning, and Ciguatera Poisoning. Additionally, palytoxin and its analogues, which are potent biotoxins produced by benthic dinoflage'1at 'c Ostreopsis spp. and Palythoa corals, may cause acute foodborne or airborn possoning outbreaks called palytoxicosis (Onuma et al., 1999; Randall, 2005; Tarı ${ }^{o l}$ one et al., 2016). Although palytoxicosis may occur upon consumption of maı ne urganisms that have grazed on Ostreopsis cells (e.g. Amzil et al., 2012), most cases are linked to direct contact with seawater or marine aerosols containing toxic cells and/or their released contents (Tubaro et al., 2011; Vila et al., 2016). In this case, the algal toxic compounds may cause cutaneous, eye and mainly respiratory irritations, and occasionally fever and neurological symptoms (Ramos and Vasconcelos, 2010). Similarly, marine and brackish cyanobacteria are known to produce toxins responsible for dermatitis (lyngbyatoxin-A, aplysiatoxin and debromoaplysiatoxin from the benthic species Lyngbya majuscula Harvey ex Gomont, 
for instance), and gastrointestinal illness in humans (nodularins from Nodularia spumigena Mertens ex Bornet \& Flahault) (Moore et al., 1993). Finally, emerging dinoflagellate toxins such as cyclic imines, gymnodimines (GYM), prorocentrolides and spirolides, produced by species like Karenia selliformis Haywood, Steidinger et MacKenzie, Prorocentrum spp. and Alexandrium ostenfeldii (Paulsen) Balech et Tangen, as well as pinnatoxins (PnTX) and portimines, produced by Vulcanodinium rugosum Nézan \& Chomérat, may also represent potential risks to human health (Delcourt et al., 2019; Molgó et al., 2016). Even though cas`s of human poisoning undoubtedly associated with emerging toxins have not $t e_{\text {. }}$ documented so far.

Most HABs, especially those associated witı toxic dinoflagellates, occur in more enclosed coastal environments with greate* $\Lambda_{\curvearrowright}$ 'drodynamic stability and usually subjected to intense economical usage, sr.c ar fjords, estuaries and sheltered bays (Berdalet et al., 2017). In Cienfueg $\&$ F ay (southern-central Cuba), many species of potentially toxic, planktonic dinofla $a_{i}$ ellates have been documented, mainly during dry periods and in small semi-confined $r$ angrove and urban areas (Moreira-González et al., 2014). Benthic toxic dinố agehates (e.g. Gambierdiscus spp., Ostreopsis spp.) also occur at high cell abuna ${ }^{n}{ }^{2}$ : principally outside the bay on coral reef environments (Díaz-Asencio et à ¿U19). Cienfuegos harbors the second largest port in the Caribbean. Considering the intense use of this urbanized region for industrial activities, maritime transport, fishing, agriculture, and tourism (Moreira-González et al., 2014), risks for shellfish- and fish-killing episodes as well as human poisoning outbreaks must be carefully considered. Fortunately, risks of foodborne human poisoning are attenuated by the current lack of commercial aquaculture in Cienfuegos Bay. However, frequent and intense recreational activities, including bathing/swimming, raise the threats to human health associated with direct contact with toxic algal compounds in seawater. 
In summer of 2015 (late July), acute skin irritation cases were recorded among swimmers in two popular recreational beaches of Cienfuegos Bay. This caused social and public health commotion, leading authorities to enforce beach closure for 68 days (Moreira-González et al., 2016). Affected people were in close contact with seawater containing a dinoflagellate-dominated bloom. This study describes relevant ecological and toxicological aspects of this bloom, and provides basic epidemiological and clinical data on the population affected by acute dermatitis. The causative organism of the bloom was investigated by means of light and scanning elecu $\urcorner n$ microscopy, and by genetic sequencing. Toxic algal compounds were dete Ini ned and quantified by liquid chromatography coupled to tandem mass spectrom ${ }^{+r y}$ in a natural phytoplankton sample collected during early bloom.

\section{Methods}

\subsection{Study site}

Cienfuegos Bay $\left(22^{\circ} 9^{\prime} \mathrm{N} \delta^{\urcorner^{\circ}} 27^{\prime} \mathrm{W}\right.$; Figure 1), located in southern-central Cuba, is a semi-enclosed emb $y \eta^{n} \epsilon_{11}$ area with estuarine characteristics. The bay has a surface area of $90 \mathrm{~km}^{2}$ and a. average depth of $14 \mathrm{~m}$. It is connected to the Caribbean

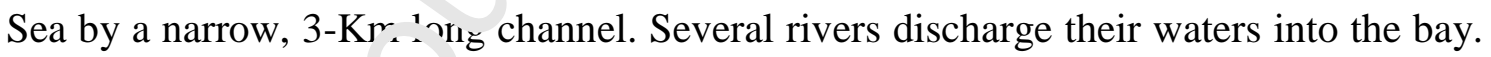
Among them, Arima Caonao, Damují and Salado possess the highest flow rates, mainly during rainy season. The northeastern basin of the bay receives most of the anthropic impact from the outfall of Cienfuegos City, with its 176,244 inhabitants (data from 2016; AEC 2017) and its industrial pole. The southeastern basin is subjected to a lower degree of anthropic pollution transported by Caonao and Arimao rivers (MuñozCaravaca et al., 2012). The bloom described herein occurred in two shallow beaches ("El Círculo Juvenil" and "La Punta"), located very close to each other along the coastline of Cienfuegos city, in the central part of Cienfuegos Bay (Figure 1). 
Weather in the study area is characterized by two marked seasons, comprising one dry (November-April) and one rainy (May-October) period. Annual precipitation averages $1256 \mathrm{~mm}$ (1967-2014 time-series), with $80 \%$ of the accumulated rainfall concentrated in the rainy season. June $(223 \mathrm{~mm})$ is the rainiest month, while December $(17.8 \mathrm{~mm})$ is the driest one (Barcia et al. 2019). Seawater temperature ranges from 25.2 to $31.2{ }^{\circ} \mathrm{C}$ during rainy season, and from 25.6 to $28.7{ }^{\circ} \mathrm{C}$ in dry season. Salinity is higher in dry periods, ranging from 33.6 to $35.0 \mathrm{psu}$, and quite variable in rainy periods, ranging from 7.3 to $34.7 \mathrm{psu}$ (Seisdedo et al., 2012). The $\mathrm{i}^{1} \mathrm{oom}$ was recorded in summer of 2015, from July to September, during rainy '

\subsection{Epidemiological data}

The cohort of the present study includer $v$ ' people who sought for medical assistance in hospitals of Cienfuegos $\mathrm{P} 0, \mathrm{n} r=$ after direct exposure to seawater containing an algal bloom. Socioder ngraphic and clinical information, including age, sex, ethnicity, degree of dermal an mage, and treatment details were obtained from medical records. This study va spproved by the institutional ethical board for epidemiological studies of the Hygiene, Epidemiology and Microbiology Center of Cienfuegos Province, Cuw:

\subsection{Phytoplank، 'n sampling}

From each of the two beaches, one surface sample of seawater was collected using a Niskin bottle at early, (July 24 2015 ) mid- (August $15^{\text {th }}$ ) and late bloom (September $8^{\text {th }} 2015$ ) and used for phytoplankton counting. Phytoplankton samples were fixed with Lugol's solution at 1\%, and maintained cooled and protected from the light until microscopic analysis. Three replicate $1-\mathrm{mL}$ aliquots of each sample were counted (entire microphytoplankton flora) on a light microscope (Olympus BX-41) at $\times 200$ magnification using Sedgwick-Rafter chamber with a detection limit of 1000 cells $\mathrm{L}^{-1}$. 
Additional water samples were taken from both beaches for qualitative analyses (identification) and semi-quantitative assessment of the bloom (i.e. relative abundance of the causative phytoplankton species). These were sampled every two to three days during the first two weeks, and weekly during the rest of the bloom. Microalgal species were identified following Tomas (1997); species/genus names were checked for validity against AlgaeBase (Guiry and Guiry, 2020). Samples from July $24^{\text {th }}$ and September $8^{\text {th }}$ were also used for selected physical-chemical analyses. Water temperature and salinity were measured in situ with a multi-parameter probe YSI-30 cu.centration of dissolved inorganic nitrogen nutrients (nitrite, nitrate and ammor un. ) were determined following the technique described in Grasshoff (1999). Phosninte concentration was measured according to UNEP (1988).

\subsection{Identification of Vulcanodinium $r$ is $s v^{\prime} m$}

Photomicrographs of Lugol-f ver. V. rugosum cells, the dominant microalgal species, were taken with a digital ca nera (Canon ELH 135) under an Olympus BX-41 light microscope. Both length an $r$. width of 40 cells were measured at $\times 1000$ magnification using an Oly. pus oil immersion objective and a micrometric ruler. For scanning electron microscin (SEM), approximately $1 \mathrm{~mL}$ of Lugol-fixed samples were filtered through a $3-r^{\prime} m$ polycarbonate membrane filter (Nuclepore), rinsed three times with distilled water, and dehydrated through an ethanol series at increasing concentrations $(10,30,50,70,90,95$, and 99.9\%). Samples were then submitted to critical point drying with $\mathrm{CO}_{2}$ to avoid cell deformation. The filters were finally mounted on an aluminum stub with carbon tape and coated with gold in a vacuum sputter coater; SEM observations were conducted under a JEOL JSM-6360 LV microscope at $15 \mathrm{kV}$ acceleration voltage. Taxonomic identification of $V$. rugosum was supported by appropriate literature (Lassus et al., 2016; Nézan and Chomérat, 2011). 


\subsection{Molecular Analyses}

\subsubsection{PCR and sequencing}

Single cells of the bloom sample, preserved in Lugol solution, were isolated under an inverted microscope (IX51, Olympus, Tokyo, Japan) and washed several times in DNA-free distilled water. Isolated single cells were transferred into 0.2-mL PCR tubes and kept at $-20^{\circ} \mathrm{C}$ until processing. The DNA sequence was directly amplified by PCR, using the KOD Hot Start DNA polymerase (Novagen). In order to increase the number of amplicons, semi-nested-PCR reactions ware nerformed. The first amplification (PCR1) was carried out with primers 1.5.W-D3B and the second amplification (PCR2), using $1 \mu \mathrm{L}$ of the PCR1 nro '1' 1 ct, was realized with primers ITSFW-28Karrev. The total reaction volume in Pr $\mathrm{k}$ - was $20 \mu \mathrm{L}$, comprised of $1 \mu \mathrm{L}$ of DNA from PCR1, $10 \mu \mathrm{L}$ of KOD Hot Sta $\mathrm{t}$ : $/ a$,ter Mix (Novagen Merck, Darmstadt, Germany), $7.8 \mu \mathrm{L}$ of DNA free wate an $\lrcorner 0.6 \mu \mathrm{L}$ of each primer (forward and reverse; $10 \mathrm{nM})$. Primers used in both rounc of PCR amplifications are described in Nézan et al. (2012).

Components of $\mathrm{PC}_{\mathbf{I}}$ reaction were directly placed in the tube containing one single Vulcanodinium c.11 Amplifications were carried out in a thermocycler Tprofessional (Bion `ra, Göttingen, Germany) with initial denaturation at $95^{\circ} \mathrm{C}$ for 2 min, 35 cycles at $95{ }^{\circ} \mathrm{C}$ for $20 \mathrm{~s}, 62{ }^{\circ} \mathrm{C}$ for $10 \mathrm{~s}$ and $70{ }^{\circ} \mathrm{C}$ for $3 \mathrm{~min}$. PCR-amplified products were visualized on an agarose gel after electrophoresis, and the positive samples were purified using the ExoSAP-IT PCR Product Cleanup reagent (Affymetrix, Cleveland, OH, USA). The Big Dye Terminator v3.1 Cycle Sequencing Kit (Applied Biosystems, Tokyo, Japan) was used for sequencing the amplicon generated at the second round of PCR. Primers and excess of dye-labeled nucleotides were first removed using the Big Dye X-terminator purification kit (Applied Biosystems, Foster City, CA, 
USA). Sequencing products were run on an ABI PRISM 3130 Genetic Analyzer (Applied Biosystems).

\subsubsection{Phylogenetic analysis}

The dataset used for phylogenetic inference from ITS-5.8S rDNA region included the sequence acquired from an isolate of the Cienfuegos Bay bloom, as well as 16 additional sequences of $V$. rugosum and 9 of other dinoflagellates retrieved from GenBank. Sequences were aligned using MAFFT' v6.502a, with the q-ins-i option that considers the secondary structure of DNA (Katoh and Standlc:, 2013). The resulting matrix included 26 sequences and 690 positions, ir ilu ${ }^{-1 n}$ gaps. The matrix was analyzed using Maximum Likelihood (ML) and $\mathbf{R}_{\mathfrak{j}}{ }^{\cdot}$ sian (BI) approaches after an initial search for the best suited substitution mode! $u^{\prime}$ 'ng jmodeltest v.2.010 (Darriba et al. 2012). It was then recommended the Thr. Ir - -Nei model with invariant sites and a gamma distribution (TN93+I+G). ML an ،yses were carried out using Phy-ML software v.3.3 (Guindon et al., 2010) and Bı ^nalyses were run with MrBayes v3.2.6 (Ronquist and Huelsenbeck, 2003). Bootstrap alysis (1000 pseudo-replicates) was used to assess the relative robustness of th $\mathrm{ML}$ tree branches. For BI analysis, 4,000,000 generations were calculated with samp 'in g every 100 generations. A burnin value of 4,000 was used and the posterior pi havilities were calculated from the 36,001 remaining trees. The consensus trees were edited using Seaview. The best ML phylograms are shown with robustness values for each node (bootstrap value bs, and posterior probability pp).

\subsection{Toxin analysis}

2.6.1. Sample preparation and extraction

On August $15^{\text {th }}, 2015$, two $250-\mathrm{mL}$ seawater samples (replicates) were collected at the surface in the most affected beach - "El Círculo Juvenil". Cells were retained on glass fiber filters (Whatman GF/F, $45 \mathrm{~mm}$ diameter, $0.8 \mu \mathrm{m}$ nominal pore size) and 
stored at $-18{ }^{\circ} \mathrm{C}$ until further treatment. Filters were extracted by sonication during 5 min using $3 \mathrm{~mL}$ of $100 \%$ methanol. Subsequently, samples were centrifuged at 3,600 $\mathrm{g}$ and $4{ }^{\circ} \mathrm{C}$ for $5 \mathrm{~min}$. The resulting supernatant was carefully recovered and the filter with cell pellet re-extracted twice in $1 \mathrm{~mL}$ of methanol. All supernatants were combined and centrifuged again at $3,600 \mathrm{~g}$ and $4{ }^{\circ} \mathrm{C}$ for $10 \mathrm{~min}$. The final supernatant $(5 \mathrm{~mL})$ was then evaporated to dryness, re-suspended in $0.5 \mathrm{~mL}$ of methanol and stored at $-20{ }^{\circ} \mathrm{C}$ until toxin analyses.

\subsubsection{Toxin detection and quantification by LC-MS/Mc}

Quantitative toxin analysis was perform $-\mathbf{u}$ on an ultra-fast liquid chromatography (UFLC) system (model UFLC simadzu), coupled to a triplequadrupole mass spectrometer (Qtrap 4000, ABSc:e $\mathrm{e}_{\lambda}$; Chromatographic separation was performed with an Hyperclone MOS C8 co'u $\left.\mathrm{u}_{1}, 50 \times 2.0 \mathrm{~mm}, 3 \mu \mathrm{m}\right)$ connected to a $\mathrm{C} 8$ guard column $(4 \times 2.0 \mathrm{~mm}, 3 \mu \mathrm{m}$, गh $\mathrm{h}$.lomenex $)$. A binary mobile phase was used, composed of phase A (100\% aque 's) and phase B (95\% aqueous acetonitrile), both containing $2 \mathrm{mM}$ ammonium frorn ${ }^{+} \mathrm{e}$ and $50 \mathrm{mM}$ formic acid. The flow rate was 0.2 $\mathrm{mL} \min ^{-1}$, and injection volı ne, $\mathrm{j} \mu \mathrm{L}$. The column and sample temperatures were $25^{\circ} \mathrm{C}$ and $4{ }^{\circ} \mathrm{C}$, respectively. $\mathrm{A}_{e}$ ra lient elution was employed, starting with $30 \% \mathrm{~B}$, rising to 95\% B over 2.5 mil, hid for $7 \mathrm{~min}$, then decreased to $30 \% \mathrm{~B}$ in $0.1 \mathrm{~min}$ and held for $3.5 \mathrm{~min}$ to equilibrate the system. LC-MS/MS was used to detect the presence of pinnatoxins, pteriatoxins and portimine. The ESI interface operated using the following parameters: curtain gas $30 \mathrm{psi}$, temperature: $450{ }^{\circ} \mathrm{C}$, gas $150 \mathrm{psi}$; gas $250 \mathrm{psi}$, ion spray voltage $5500 \mathrm{~V}$. Transitions and MS/MS parameters used for the multiple reaction monitoring (MRM) in positive ionization mode are reported in Table 1. All toxins were quantified against the PnTX-G standard from National Research Council Canada (Halifax, Canada), assuming that all investigated compounds (pinnatoxins, pteriatoxins 
and portimine) had the same response factor as PnTX-G.

\subsubsection{Confirmatory toxin identification by HRMS}

Accurate mass data were acquired on a quadrupole time-of-flight (QTOF) mass spectrometer (QTOF 6540, Agilent) equipped with a dual electrospray ionization (ESI) source coupled to an Agilent 1200 HPLC system. Separation was carried out on a Kinetex C18 Phenomenex column $(100 \times 2.1 \mathrm{~mm}, 2.6 \mu \mathrm{m})$ at $40{ }^{\circ} \mathrm{C}$. A flow rate of 0.4 $\mathrm{mL} \min ^{-1}$ was applied, using a linear gradient elution from $5 \%$ B to $50 \%$ B over 3.6 min, then increased to $100 \%$ within $5 \mathrm{~min}$, held for $1.5 \mathrm{~min}$ hel re returning to $5 \% \mathrm{~B}$ to equilibrate the system for 5 min. Mobile phase A was cu nstituted of $100 \%$ water and phase B of $95 \%$ acetonitrile with $5 \%$ water, both conı ining $2 \mathrm{mM}$ ammonium formate and $50 \mathrm{mM}$ formic acid. The instrument was $\mathrm{ppe}^{\text {ted }}$ in positive ionization mode, performing full-scan analysis over $m / z, 1 l^{r}-1 / 00$ at 2 spectra $\mathrm{s}^{-1}$. Capillary and fragmentor voltages were $3500 \mathrm{~V}$ and $200 \mathrm{~V}$, respectively. Temperature of the Jet Stream Technologies source was $2 \mathrm{v}^{-}{ }^{\circ} \mathrm{C}$, with drying gas at $5 \mathrm{~L} \mathrm{~min}^{-1}$ and sheath gas at $12 \mathrm{~L} \mathrm{~min}^{-1}$ at $355^{\circ} \mathrm{C}$.

\section{Results}

\subsection{Demographic ... ${ }^{-}$.inical aspects of the affected population}

Dermatitis cas's were reported by people after sea bathing in "El Círculo Juvenil" and "La Punta" beaches (Cienfuegos Bay) on July $23^{\text {rd }}$ and $24^{\text {th }}$, 2015, with most cases occurring in the first location. Sites with reported cases coincided with the shoreline areas in which reddish-brown water discolorations of $V$. rugosum were noticeable during these dates. There were no reported cases in the remaining recreational areas of the bay. In total, 60 people were assisted in the hospitals of Cienfuegos province due to skin problems. All patients had spent at least two hours in the seawater in the affected areas. Of these, 49 cases (81.6\%) were male and $11(18.3 \%)$ 
female. Children between 0 and 14 years-old comprised $79.2 \%$ of the studied cases; the average $( \pm \mathrm{SD})$ age of patients with dermatitis was $11.7 \pm 4.6$ years (Table 2$)$. Patients were all native Cubans and residents of Cienfuegos City or surrounding areas. It should be noted that dermatitis cases were limited to a short period (July $23^{\text {rd }}-24^{\text {th }}$ ) because all beaches in Cienfuegos Bay were closed by local authorities from July $25^{\text {th }}$ on, and residents avoided these recreational areas until the algal bloom had ceased. There was no report of health problems associated to inhalation of aerosol sprays during the bloom.

All patients suffered acute dermal irritation wiı intense itching and eczema. Skin lesions concentrated mainly in the wettest parts,$f$ the body (inguinal and genital areas, pelvic region and gluteus), usually delineatiı ${ }_{c}$ the swimsuit of affected people. Erythematous blisters and itching appearec w thin 3-4 hours of contact with the bloom, leading to ulcerative lesions that b ar a e secondarily infected, assuming a reddish, pustular and crusty aspect. The tratment for affected patients consisted mainly of fomentation with fresh, boiled ver, anti-histaminics, topical corticosteroids and antibiotics (to avoid infectic. 's), administrated during seven days. There were no clinical complications with most at $^{\text {at }}$ ents, although five children remained hospitalized during up to five days al 'r ueveloping more severe infection-like processes. In overall, patients recovered within seven to ten days without long-term effects.

\subsection{Environmental data and phytoplankton assemblage}

Mean values of seawater temperature and salinity were similar at early and late bloom periods, ranging from $32{ }^{\circ} \mathrm{C}$ in July to $31.9{ }^{\circ} \mathrm{C}$ in September, and from $35.4 \mathrm{psu}$ in July to 34.9 psu in September, respectively. The concentrations of inorganic nutrients varied (from July to September) from 0.34 to $0.25 \mu \mathrm{mol} \mathrm{L}^{-1}$ of nitrite, 0.1 to $0.37 \mu \mathrm{mol}$ $\mathrm{L}^{-1}$ of nitrate, 3.85 to $2.12 \mu \mathrm{mol} \mathrm{L} \mathrm{L}^{-1}$ of ammonium, and from 0.43 to $0.46 \mu \mathrm{mol} \mathrm{L}^{-1}$ of 
phosphate. With the exception of ammonium in July $\left(3.85 \mu \mathrm{mol} \mathrm{L}^{-1}\right)$, nutrient concentrations were mostly below those established by the NEPC (National Environment Protection Council) as the threshold concentrations related to waters under eutrophication process (NEPC 1999).

The bloom was characterized by red-brownish, large discontinuous patches, 3 to $10 \mathrm{~m}$ distant from the shoreline along "El Círculo Juvenil" and "La Punta" beaches. The discolored water mass was $\sim 0.7-\mathrm{Km}$ long, with a maximum depth of $\sim 1.2 \mathrm{~m}$ (Figure 2), and exhibited a strong "seafood-like" odor at early stages It +arted to be noticed on July $23^{\text {rd }}$, when the dinoflagellate $V$. rugosum dominat $₫$ ¿ 'e phytoplankton assemblage at cell abundances as high as $9.6 \times 10^{7}$ cells $\mathrm{L}^{-1}$ (meaı $4.2 \times 10^{7}$ cells $\mathrm{L}^{-1}$ ). Average $V$. rugosum cell densities decreased slightly to $2.4 \times \cdot 1^{7}$ cells $\mathrm{L}^{-1}$ on August $15^{\text {th }}$ and persisted $>10^{7}$ cells $\mathrm{L}^{-1}$ until $27^{\text {th }}$ Augurt, $\mathrm{h} \mathrm{n}_{\mathrm{n}}$ dropping to $6.5 \times 10^{6}$ cells $\mathrm{L}^{-1}$ on September $8^{\text {th }}$. The bloom remained ass intense (on the order of $10^{6}$ cells $\mathrm{L}^{-1}$ ) over its final month, but the water discolorai nn was still clearly visible, mainly as patches, until September $20^{\text {th }}$. The beaches ren ned closed until September $30^{\text {th }}$. Co-occurring diatoms (Bacteriastrum de'icatulum Cleve, Thalassionema nitzschioides (Grunow) Mereschkowsky) and oth - $r$ inoflagellates - including several red tide-forming species such as Blixaea quı. 'utcornis (Abé) Gottschling, Prorocentrum compressum (Bailey) Abé ex Dodge, Prorocentrum micans Ehrenberg, Tripos furca (Ehrenberg) Gómez and T. trichoceros (Ehrenberg) Gómez - were detected at much lower cell densities (Table 3). The DSP-producing species Dinophysis caudata Saville-Kent was only registered in net-concentrated samples.

\subsection{Cell morphology of the causative species, Vulcanodinium rugosum}

Vulcanodinium rugosum Nézan \& Chomérat 2011 is an armoured, solitary dinoflagellate. Motile cells are biconical to round in ventral view. Epitheca of the 
examined cells is conical to hemispherical, truncated at the apex, while the hypotheca is trapezoidal to hemispherical and acuminate at the antapex. Numerous golden-brown chloroplasts, as well as an elongated, equatorially placed nucleus are visible under light microscopy (LM). All motile cells exhibit a distinctive apical pore complex, with remnants of mucilaginous material, as observed by scanning electron microscopy (SEM). Additionally, all thecal plates are ornamented with numerous circular trichocyst pores and prominent longitudinal ridges - other typical features of the species. In this species, the first apical plate $\left(1^{\prime}\right)$ is very narrow and inva ${ }_{11}$ ?ted, running from the apical pore complex to the anterior margin of the cirgulum. Sulcus is sigmoid, anteriorly narrow, becomes wider posteriorly and rt. ches the antapex. Cingulum is wide, descending 1.5-2 times its own width. Moti'e $\sim$-1l length (L) ranged from 22 to 31 $\mu \mathrm{m}\left(26.3 \pm 2.48 \mu \mathrm{m} ;\right.$ average \pm standard $\left.\mathrm{d} v v^{\circ}+\mathrm{i}^{\prime}, \mathrm{n}\right)$, and cell width (W) from 18 to 27 $\mu \mathrm{m}(23.0 \pm 1.90 \mu \mathrm{m})$, with an avera $\mathrm{J} / \mathrm{W}$ ratio of $1.15 \pm 0.10$ (Figure 3). Spherical, cyst-like cells (non-motile cells) c cclosed in a gelatinous matrix were also found abundantly in the samples (Figrre: R).

\subsection{Molecular analysis and phylogeny}

The morphologicai ir entification of $V$. rugosum was confirmed genetically by sequencing the inte. 11 ranscribed spacers ITS1 and ITS2 and the 5.8S rDNA region and a phylogenetic analysis (Figure 4). Sequences were deposited into the National Center for Biotechnology Information's repository (GenBank) under the accession number MT622540. The ML tree revealed that all sequences of $V$. rugosum clustered in a robust monophyletic clade distant from other dinoflagellates genera (Figure 4). Within this clade, the sequences clustered in three separate, well-resolved subclades, named A, B and C (Figure 4). Subclade A contained three sequences of strains isolated from southern French lagoons, including the reference sequence IFR10-027 from the type 
locality. Subclade B included five sequences of strains isolated from New Zealand, three from Australia and one from China. Subclade C included the sequence from Cienfuegos Bay bloom and two sequences that were found to be almost identical: one from Japan (strain CAWD188) and one from the isolate CAFWC516, collected and isolated from ballast residuals of the merchant vessel Southern Fighter in Port Tampa Bay, Florida, USA. Two other sequences from Japan and Qatar clustered in subclade C, but were more basal than the Cuban sequence (Figure 4).

\subsection{Toxins}

The bloom sample collected for toxin determina .un. contained V. rugosum at 2.4 $\times 10^{7}$ cells $\mathrm{L}^{-1}(99.97 \%$ of the total microphytnnınkton abundance). Cells of $V$. rugosum contained several toxic compounds, maiı:" pinnatoxin (PnTX)-F (441.8 fg cell $\left.^{-1}\right)$, portimine $\left(356.6 \mathrm{fg} \mathrm{cell}^{-1}\right)$ and $\mathrm{PnTY}_{-\llcorner}\left(\mathrm{O}^{-}+2 \mathrm{fg} \mathrm{cell}^{-1}\right)$, as well as trace amounts of PnTX-D, PnTX-G, and of PnTX-L an $\_-F$ isomers (Table 4, Figure 5). Exact masses obtained by HRMS analysis confu ned the presence of portimine, PnTX-E, PnTX-E isomer, PnTX-F and PnTX-F is ' $n$ er, with $\Delta$ ppm values below $5 \mathrm{ppm}$ for each compound (Table 4). In adc tion, the presence of a compound with the same exact mass of 7-methyl PnTX-E and a 7 methyl PnTX-E isomer were also detected ( $\Delta \mathrm{ppm}$ : 3.8 and 1.8, respectively). the uthers toxins, PnTX-D and PnTX-G, were present at levels below the detection limit of HRMS system.

\section{Discussion}

Vulcanodinium rugosum is the only known producer of pinnatoxins and portimine, cyclic imine toxins considered as emergent threats to human health and challenges to the shellfish industry (Arnich et al., 2020). Pinnatoxins are neurotoxic compounds while portimine has demonstrated cytotoxic activity to mammalian cells; however no human illnesses associated with these toxins - or with any other emerging 
algal toxin - have been described so far (Delcourt et al., 2019; Molgó et al., 2016). This study reports for the first time the occurrence of V. rugosum in western Atlantic waters, and presents the first evidences associating a $V$. rugosum bloom with adverse effects to human health. It also offers insights on the possible implications of ballast water exchange and extreme weather conditions (namely increased temperature coupled to droughts) for the occurrence of harmful episodes like the one described herein.

\subsection{Dermatitis outbreak associated with a V. rugosum bloom}

The present study represents the first description oi a $V$. rugosum bloom associated with dermatitis cases worldwide. In our stu $\lrcorner$, cases of skin irritation were reported in people exposed to the bloom in the two ieaches affected by the event in Cienfuegos Bay, Cuba. Although skin injuries carse hy coelenterates are very frequent in Cuba during summer months (He an.'nd zz-Leyva, unpublished data), their characteristic clinical signs are somer ha $^{+}$different from those observed in most patients in contact with the bloom. Furtherm $\checkmark$ re, no incidents with jellyfish were reported in the affected area during the present in re,tigation. Skin lesions in patients who had contact with the $V$. rugosum bloom : ecanle quickly infected and purulent, and most patients had to be treated with antihic ic,. Some children were more seriously affected, requiring hospital care for a $\mathrm{N}$ w uays, possibly because they normally last much longer in the water thus prolonging the contact with the bloom. There was no other obvious explanation (e.g. toxic chemicals, parasites or other pathogens) to the skin irritation cases described herein. This suggests that dermatitis in beachgoers was strongly associated with algal compounds produced during the massive $V$. rugosum bloom. In this context, it is assumed that such toxic compounds must have been partially released into the water, as commonly reported for other lipophilic toxin-producing dinoflagellates such as Karenia brevis (Davis) Hansen et Moestrup (Pierce and Henry, 
2008) and Dinophysis spp. (Mafra et al., 2016).

Certain species of marine dinoflagellates and cyanobacteria have been linked to previous cases of dermatitis in beachgoers worldwide. Toxic blooms of the dinoflagellates $K$. brevis and Ostreopsis cf. ovata Fukuyo, for instance, are of great concern to public health in the Gulf of Mexico and the Mediterranean Sea, respectively (Berdalet et al., 2016). During massive bloom episodes involving these species, beach users have experienced dermal irritation from direct contact with seawater, as well as other health disorders including respiratory problems, eye and $\mathrm{h}$ 'se irritation, fever, and general malaise, caused mostly by exposure to sea-spra y a rosols (Fleming et al., 2011; Vila et al., 2016). Marine-estuarine cyanobacteria suc: as the benthic species Lyngbya majuscula can also produce dermatotoxic compran' $\varsigma$, and have been associated with reports of skin and eye irritations during bl $\curvearrowright$ o. in s episodes (Osborne and Shaw, 2008). A strong association between cyanot ct ital abundance and the development of illness after recreational exposure has been tocumented in Boquerón Beach, Puerto Rico (Lin et al., 2016), with symptoms in lu $^{\prime}{ }^{\prime i r}$ g eye irritation, respiratory disorders, earache and rash. Contrary to beachgoe1: affected by blooms of either toxic cyanobacteria, $K$. brevis or $O$. cf. ovata, however, ${ }^{a^{+}}$ents in contact with the $V$. rugosum bloom in Cienfuegos Bay did not exhibı any signs of eye irritation, respiratory problems or neurological symptoms. Instead, only dermatological symptoms were reported.

Species causing dermal irritation such as L. majuscula and $O$. cf. ovata have been previously recorded in Cienfuegos Bay (Moreira-González et al., 2014). Nevertheless, they were not detected during the bloom event described herein. The few co-occurring dinoflagellate and diatom species were barely detected in our plankton samples $\left(1.0-6.5 \times 10^{3}\right.$ cells $\left.\mathrm{L}^{-1}\right)$ and are not known as toxin producers. The only other potentially toxic $\mathrm{HAB}$ species found co-occurring with $V$. rugosum was the 
dinoflagellate Dinophysis caudata. However, this species, which occurred at very low cell density $\left(<1.0 \times 10^{3}\right.$ cells $\left.\mathrm{L}^{-1}\right)$, produces only diarrhetic toxins and pectenotoxins rather than fast-acting, potential dermatitis-promoting compounds. Considering (i) the close association between the distribution of the bloom and the incidence of dermatitis cases, (ii) the nearly monospecific nature of this algal bloom, and (iii) the absence of other known, acute dermal irritants in the water, V. rugosum remains the only plausible candidate explaining the outbreak reported in Cienfuegos Bay in summer 2015. Moreover, our epidemiological results indicate that children $m_{a_{j}}$ be more susceptible to the harmful effects of $V$. rugosum blooms via direct ex pu ure during likely longer and more frequent sea bathing activity.

\subsection{V. rugosum toxinology}

Eight pinnatoxins, named PnTX-A tc $-\mathrm{H}$, have been described so far from $V$. rugosum cells and accumulated in si alls sh (Chou et al., 1996; Selwood et al., 2010, 2014; Takada et al., 2001; Uemura ` + al., 1995). The types and amounts of pinnatoxins vary largely among distinct $V$. $\because g_{c} \backsim m$ strains, especially among isolates from different geographical locations (Rhe les ti al., 2011a). Cells of $V$. rugosum collected during the Cuban bloom exhibited tuvi, profiles comparable to those originated from the Pacific Ocean, particularly ' 'livated cells from New Zealand and Australia, which produced mostly the cyclic imines pinnatoxin (PnTX)-E and PnTX-F, with the latter as the most abundant toxic compound in all cases (Rhodes et al., 2010, 2011a, 2011b; this study). However, New Zealand/Australian strains exhibited approximately 5 to 80 -fold higher intracellular concentrations of PnTX-F (2.3-41.0 pg cell $\left.{ }^{-1}\right)$ and 4 to 100 -fold higher concentrations of PnTX-E (0.40-10.0 $\left.\mathrm{pg} \mathrm{cell}^{-1}\right)$ than those reported during the Cuban bloom (Rhodes et al., 2010). Additionally, cells from the Cuban bloom contained relatively high levels of another cyclic imine, portimine $\left(\sim 0.4 \mathrm{pg} \mathrm{cell}^{-1}\right)$, as well as trace 
amounts of PnTX-D and possibly of PnTX-G, and isomers of PnTX-E and PnTX-F. In contrast, much less diverse toxin profiles have been registered in other cases. The strain isolated from a ballast tank in Florida contained exclusively portimine (Garrett et al., 2014) and a Mediterranean strain of V. rugosum contained only portimine and PnTX-G (Hess et al., 2013; Geiger et al., 2013). The latter compound, in fact, can be moderately to highly abundant in Mediterranean (0.14-4.7 pg cell $^{-1}$ ) and in Pacific (Japan/Australia) strains (11.9-87.0 $\mathrm{pg} \mathrm{cell}^{-1}$ ), respectively (reviewed in Abadie et al., 2016). Related to portimine, although its occurrence was vastly documented Rhices et al., 2011; Smith et al., 2011; Hess et al., 2013; Selwood et al., 2013; A Jav'ie et al., 2015, 2016), this is the first report of intracellular levels in $V$. rugosur cells, so that no comparative assessment among geographical areas is possible $: \pm l^{\prime} \cdot{ }^{\prime} s$ point.

Pinnatoxins are potent competitive an , or nists of neuronal and muscle nicotine acetylcholine receptors (nAChRs), c 'ls'ng paralysis after blocking nAChRs through high-affinity, persistent attachment in multiple anchoring points in a specific receptor binding site (Araoz et al., 2011 • Bc rrae et al., 2015; Hellyer et al., 2015; Selwood et al., 2010). Pinnatoxins are fast cting compounds, highly toxic to mice by intraperitoneal (i.p) injection and oral in' $\cdot \mathrm{k}$ e, usually taking longer times to onset of symptoms and death via feeding, a. tested for PnTX-E to -H (Munday et al., 2012; Selwood et al., 2010; Sosa et al., 2020). In mice, symptoms following lethal dose include decrease of activity or immobility preceded of hyperactivity (except for PnTX-H), piloerection, prostration, tremors, hypothermia, jumping, hind leg extension/paralysis, abdominal breathing abruptly progressing to decrease in respiratory rate, cyanosis, exophthalmia and death (Munday et al., 2012; Selwood et al., 2010; Sosa et al., 2020). Acute toxicity, both via oral intake and i.p route, varies substantially among different pinnatoxins, being higher in PnTX-F (reviewed in Arnich et al., 2020), the dominant form in the 
Cuban bloom sample. In humans, possible symptoms of PnTX intoxication via oral intake, as derived from pharmacologically similar compounds, would include the anticholinergic syndrome, pyramidal syndrome, muscle weakness, dyspnea, dysautonomia and seizures (Delcourt et al., 2019). Portimine, in contrast, exhibits very low acute toxicity to mice after i.p. injection, but is highly cytotoxic to different cultivated cell lines, including murine lymphoblastoid cells (Selwood et al., 2013), human Jurkat T-lymphoma cells and mouse embryonic fibroblasts (Cuddihy et al., 2016). Even at very low doses $\left(\mathrm{LC}_{50}: 2.5-6.0 \mathrm{nM}\right)$, prrtin. apoptosis - but not cell necrosis - leading to cell deat', , 'hereas PnTx-F and PnTx-G caused no cytotoxicity at concentrations up to $1 \mu \mathrm{M}\left(\mathrm{C}^{\mathrm{I}} \mathrm{Iddihy}\right.$ et al., 2016). Up to date, however, no human intoxication episode has beer. $u$.' doubtedly linked to cyclic imines including pinnatoxins and portimine (ANSE⿺ 2'19; Arnich et al., 2020; Molgó et al., 2016).

As the only known PnTX - producing organism, V. rugosum is the suspect causative agent of PnTX contamini + i , n episodes in shellfish from different coastal areas of Canada, Ireland, Italy, Nirway, Slovenia and Spain (McCarron et al., 2012; RamblaAlegre et al., 2018; Rundı ‘rs,et et al., 2011). Toxins from V. rugosum have thus become an emerging threat $\backsim$ suafood consumers, even though cells of this species have been hardly observed in the water column during such shellfish contamination episodes (Arnich et al., 2020). The present study attributes to V. rugosum an additional category of adverse effects to human health, and expands the global distribution of this dinoflagellate to the West Atlantic Ocean, thus enhancing its potential negative impacts in coastal regions worldwide. Further investigations are necessary to clarify which compound(s) was/were responsible for the dermatotoxic effects observed in swimmers after exposure to V. rugosum in Cienfuegos Bay. 
Since apoptosis of epithelial cells is involved in different skin diseases and lesions (reviewed in Ahmadi Ashtiani et al., 2019), and considering the selective, strong apoptosis-promoting capacity of portimine, this compound is a potential candidate. Eczematous dermatitis cases, including those caused by direct contact with irritating substances or by an allergic reaction to them ("contact dermatitis"), are manifested upon the apoptosis of keratinocytes, the primary, outermost skin cells (Norris et al., 1997). Keratinocyte apoptosis seems to be regulated by inflammatory processes mediated by type 2 and type 1 cytokines such as the IFN-g, producer hy kin-infiltrating T-cells

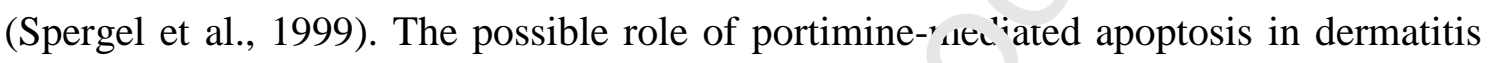
must be therefore investigated in cell and animal modt.s. Alternatively, nAChRs can be expressed abundantly in non-neural locations, surh is the keratinocytes (Arredondo et al., 2002). In this sense, the role of select $v a n / C h R$ blockers such as pinnatoxins in triggering pruritus and dermatitis fo: nw ng dermal exposure may be also considered. To the best of our knowledge, the 1 i is no study assessing the potential dermatotoxic effects of V. rugosum compounds, nr,luding portimine and pinnatoxins.

\subsection{Geographical distr : hutıon and phylogenetics of $V$. rugosum}

Vulcanodinium $r u_{\delta} \curvearrowright \mathrm{sm}$ was first described from samples collected in Ingril, a French Mediterrant. $\eta$ iagoon, in 2011 (Nézan and Chomérat, 2011). Its global distribution was then quickly expanded by reports of its occurrence in the eastern Pacific (Mexico) (Hernández-Becerril et al., 2013), western Pacific (Australia, New Zealand, Japan, China) (Rhodes et al., 2010, 2011b; Smith et al., 2011; Zeng et al., 2012) and Indian Ocean (Persian Gulf) (Al Muftah et al., 2016). The occurrence of $V$. rugosum in Cienfuegos Bay during the bloom described herein thus represents the first report of this species in Western Atlantic waters.

The lack of previous reports of this species in Cienfuegos Bay during the regular 
plankton monitoring carried out by public authorities since 2000 (Moreira-González et al., 2014) suggests a recent introduction of the species into Cuban waters. Transport of dinoflagellate cysts and non-motile cells represents a common dissemination mechanism for harmful species, and involves natural (e.g. currents) and a wide range of anthropogenic vectors including relocation of aquaculture stocks and sediments, and ballast water exchange (Anderson et al., 2012). In fact, V. rugosum was earlier isolated from a vessel ballast tank in Port Tampa Bay, Florida, USA, a coastal region relatively close to Cuban waters (Garrett et al., 2014). Both the ship's halı st exchange history and phylogenetic analyses of the LSU and ITS rDNA itzions of the Florida isolate suggested that it originated from Japanese waters ( $\mathcal{\text { . }}$ rrett et al. 2014). Interestingly, results from the present study point out that the renotype found in Cuban waters belongs to subclade $\mathrm{C}$ of $V$. rugosum, which i. \& 1 een previously identified in the ballast tank in Florida, as well as in st in from Japan and Qatar. Hence, molecular phylogenetic data strongly supports : he hypothesis of introduction of $V$. rugosum in the area, possibly via ballast water in suips coming from the Pacific Ocean through the Panama channel. However, whesher or not the appearance of V. rugosum in Cuba is related to an earlier intru ${ }_{1}$ tion into Florida's waters remains to be elucidated. As previously discussea, thu toxin profile of $V$. rugosum cells sampled during the bloom in Cuba (producing portimine and PnTXs) differed from that of cells originated from the ballast water in Florida (composed of portimine only). This supports a marked variation in PnTX profile among V. rugosum strains from different regions (Rhodes et al., 2011a), and suggests distinct origins for cells sampled in Cuba and those isolated from the ballast tank in Florida. Moreover, the establishment of invasive V. rugosum populations has yet to be documented in Florida.

\subsection{Environmental conditions associated to the exceptional V. rugosum bloom}


In 2015 and 2016, Cuba was strongly influenced by the El Niño Southern Oscillation (ENSO) associated with exceptionally high air temperatures from July to October of 2015 (Barcia-Sardiñas et al., 2020), coinciding with the period of $V$. rugosum bloom in Cienfuegos Province. During that entire period, positive daily temperature anomalies were frequently recorded, and new historical maximum temperatures were registered every month: $37.0{ }^{\circ} \mathrm{C}$ for July, $36.4{ }^{\circ} \mathrm{C}$ for August, $35.2{ }^{\circ} \mathrm{C}$ for September and $34.6{ }^{\circ} \mathrm{C}$ for October. The maximum value registered on July $6^{\text {th }}$ represents the highest absolute temperature value ever recordea : 7 Cienfuegos Province. On average, July 2015 was the third warmest month in -4 : a since the data started to be regularly documented in 1951 , with a mean air ? mperature of $28.2{ }^{\circ} \mathrm{C}$, which represented a $+0.7{ }^{\circ} \mathrm{C}$ anomaly for that montt (.'CM, 2015; Barcia-Sardiñas and Caballero-Reyes, 2017; Barcia-Sardiñas et al., ’n 20). Such high temperatures registered in central-southern Cuba in July 2015 we.e triggered by the prevalence of high-pressure systems, high solar irradiance, calı weather (gentle winds), and reduced cloud cover (Barcia-Sardiñas et al., 2020). Tho e are usually favorable conditions to the occurrence and persistence of dinoflag: ${ }^{1}$ late blooms in Cienfuegos Bay (Moreira-González et al., 2014). Moreover, a lahor tr iy study has underlined the thermophilic character of $V$. rugosum, whose ct.'s 1 eached its maximum abundance, chlorophyll- $a$ content and PnTX-G levels at $30{ }^{\circ} \mathrm{C}$ (Abadie et al., 2016), similar to the seawater temperature recorded in Cienfuegos Bay during the bloom $\left(32{ }^{\circ} \mathrm{C}\right)$.

Another climatic factor contributing to the occurrence and persistence of the $V$. rugosum bloom was the drought period that affected Cienfuegos Province before and during the event. July 2015 can be considered the driest July since 1981, with a cumulative rainfall of $84.7 \mathrm{~mm}$ representing $<50 \%$ of the previous historical minimum (Barcia-Sardiñas et al., 2019). From May to July - the first three months of the so- 
called rainy period in Cuba (May-October) $-84.8 \%$ of the territory were affected by rainfall deficits in 2015 (BCM, 2015; Barcia-Sardiñas et al., 2019). Therefore, abnormally high salinity values (34.9-35.4 psu), which would be typical of dry periods in Cienfuegos Bay, persisted during the $V$. rugosum bloom as a result of low riverine freshwater inputs (due to low precipitation). In semi-enclosed embayments such as Cienfuegos Bay, this condition also promotes low turbulence leading to high water residence times and/or marked water column stability, which are ultimately suitable conditions for dinoflagellate blooms in coastal waters (Vila et .1., 2001). Additionally, Mediterranean strains of $V$. rugosum exhibited high I $_{2}$ rowth rate with increasing salinity (30 to $40 \mathrm{psu}$ ) in laboratory cultures (Abadje eı ^l., 2016).

Moderate concentrations of ammonium, $r h_{1} \cdot h$ were slightly higher than usual for this period of the year in the bloom an + Moreira et al., 2014), may have also stimulated the bloom in Cienfuegos $I$ ay since this nitrogen form is rapidly assimilated by V. rugosum (Abadie et al., 2015,. This species, like many other dinoflagellates, may be better adapted to use ammnni $r_{1}$ and other organic nitrogen forms like urea, in comparison for instance wit' diaıoms, which are specialized nitrate users (Abadie et al., 2015; Burkholder et al.. ¿רก 3; Glibert et al., 2016; Kudela et al., 2005). Additionally, there is evidence tha thu central-southern coast of Cuba received inputs of Saharan dust during the bloom period. Increased atmospheric flux of both macronutrients (e.g. nitrogen, phosphorus) and trace metals was reported at the beginning of the $V$. rugosum bloom (July 2015) in the coastal area of Cienfuegos Bay (Morera-Gómez et al., 2018, 2019), which might have also contributed to this bloom development and persistence via nutrient enrichment (Walsh and Steidinger, 2001). Increasing ocean temperature and nutrient input due to global climate change and pollution may thus lead V. rugosum blooms to become more frequent and to expand their distribution towards subtropical 
and temperate zones, as indicated for other HAB-forming species (Anderson et al., 2014; Heisler et al., 2008; Wells et al., 2015). The occurrence of massive planktonic (pelagic) blooms of $V$. rugosum is a special concern to human health in semi-enclosed coastal systems with recreational and tourism use like Cienfuegos Bay, as well as in similar areas used for shellfish farming. The motile, pelagic form of this dinoflagellate is assumed to represent its vegetative life cycle phase, resulting from asexual cell divisions, while the related benthic form would represent the sexual phase (Zeng et al., 2012). The environmental triggers regulating the transition be:veen both phases, and the prevalence of pelagic forms as reported here, are sti' ${ }^{\prime} u_{1}$ known.

\section{Conclusions}

Overall, this study suggests a link betveen a dinoflagellate bloom and the occurrence of an outbreak of acute derm? in:adtion in Cienfuegos Bay (Cuba), with children being the most affected peralation. The bloom was also associated to anomalous weather conditions surh a frequent and prolonged droughts together with high temperatures in the rain! s. $\eta_{m}$ er season in Cuba. Combined morphological and genetic characters indicated the presence of Vulcanodinium rugosum as the causative agent of the bloom. The pedominant toxins in cells collected from the bloom were portimine, PnTX-E a. 1 PnTX-F, similar to toxin profiles of other $V$. rugosum strains originated from the Pacific Ocean. Since toxic events with human victims related to $V$. rugosum were previously unknown, further investigations are necessary to clarify which compound(s) was (were) responsible for the dermatotoxic effects described herein. Due to its strong cytotoxic, apoptosis-induction effect, portimine is a potential candidate, but the role of pinnatoxins and/or other compounds cannot be discarded. Based on phylogenetic evidence, it is suggested that $V$. rugosum may have been recently introduced into Cuban waters, possibly via ballast water from the Pacific Ocean. 


\section{Acknowledgements}

This work was supported by the Ministry of Science, Technology and Environment of Cuba (CITMA) and the International Atomic Energy Agency (IAEA) (RLA-7020). The authors acknowledge the support of Ms. D. Chamero and the staff of the Water Quality Laboratory from Cienfuegos Center for Environmental Studies (CEAC, Cuba) for their help with sampling, Ms. L. Castellanos for her assistance with graphic design, the Center of Electronic Microscopy of the Federal University of Parana (UFPR, Brazil) for making their equipment available for this study, and to the meci al team of Cienfuegos

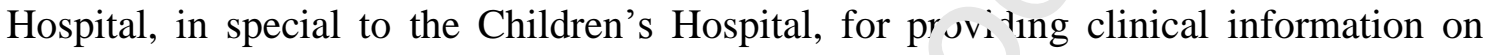
dermatitis cases. ARM-G is grateful to the Coordenacai de Aperfeiçoamento de Pessoal de Nível Superior (CAPES, Brazil) for the Ph J. cholarship (2014-2018) awarded through the co-funded PEC-PG Program.

\section{References}

Abadie, E., Kaci, L., Berteaux, T., Hı`s, P., Séchet, V., Masseret, E., Rolland, J.L., Laabir, M., 2015. Effect of nitrate, ammonium ani urea on growth and pinnatoxin $G$ production of Vulcanodinium rugosum. Mar. Drug ' 3, j642-5656. https://doi.10.3390/md13095642.

Abadie, E., Muguet, A., Berte ıux, T., Chomérat, N., Hess, P., Roque, D’OrbCastel, E., Masseret, E., Laabir, M., 201 1. 1 xin and growth responses of the neurotoxic dinoflagellate Vulcanodinium rugosum to varying temperature and salinity. Toxins 8, 136. https://doi.10.3390/toxins\&า501 ;S.

AEC (Anuario Estadís ico te Cienfuegos), 2017. Anuario Estadístico de Cienfuegos 2016. Oficina Nacional de .'slu’ stica e Información (ONEI). http://www.onei.cu (accessed 15 May 2020).

Ahmadi Ashtiani, H.R., Zakizadeh, S., Khanahmadi, M., Nilforoushzadeh, M.A., Zare, S., 2019. Apoptosis in Hair and Skin: A Review. J. Skin Stem. Cell 5, e86099. https://doi: $10.5812 /$ jssc.86099.

Al Muftah, A., Selwood, A.I., Foss, A.J., Al-Jabri, H.M.S., Potts, M., Yilmaz, M., 2016. Algal toxins and producers in the marine waters of Qatar, Arabian Gulf. Toxicon 122, 54-66. https://doi.10.1016/j.toxicon.2016.09.016.

Amzil, Z., Sibat, M., Chomérat, N., Grossel, H., Marco-Miralles, F., Lemée, R, Nézan, E., Séchet, V., 2012. Ovatoxin-a and palytoxin accumulation in seafood in relation to Ostreopsis cf. ovata blooms on the French Mediterranean coast. Mar. Drugs 10, 477-496. https://doi.10.3390/md10020477.

Anderson, C.R., Moore, S.K., Tomlinson, M.C., Silke, J., Cusack, C.K., 2015. Living with harmful algal blooms in a changing world: strategies for modeling and mitigating their effects in coastal marine ecosystems, in: Shroder, J.F., Ellis, J.T., Sherman, D.J. (Eds.), Coastal and Marine Hazards, Risks, and Disasters. Elsevier, Amsterdam, pp. 495-561. 
Anderson, D.M., 2014. HABs in a changing world: a perspective on harmful algal blooms, their impacts, and research and management in a dynamic era of climatic and environmental change, in: Kim, H.G., Reguera, B., Hallegraeff, G.M., Lee, C.K. (Eds.) Harmful Algae 2012: Proceedings of the 15th International Conference on Harmful Algae, October 29-November 2, 2012, CECO, Changwon, Gyeongnam, Korea, pp. 3-17.

Anderson, D.M., Cembella, A.D., Hallegraeff, G.M., 2012. Progress in understanding harmful algal blooms: paradigm shifts and new technologies for research, monitoring, and management. Ann. Rev. Mar. Sci. 4, 143-176. https://doi.10.1146/annurev-marine-120308-081121.

Anderson, D.M., Kaoru, Y., White, A.W., 2000. Estimated Annual Economic Impacts from Harmful Algal Blooms (HABs) in the United States. Technical Report WHOI-2000-11. Woods Hole Oceanographic Institute, Woods Hole. https://apps.dtic.mil/sti/citations/ADA386861.

ANSES (Agence Nationale de Sécurité Sanitaire)., 2019. Risques liés aux pinnatoxines dans les coquillages. Direction générale de l'alimentation (DGAL) et Direction générale de la santé (DGS), France, Ref. Avis de l'Anses. Rapport d'expertise collect ^ Saisine « 2016-SA-0013» Pinnatoxines. Technical R $136 \mathrm{p}$. https://www.anses.fr/fr/system/files/ERCA2016SA0013Ra.pdf ( Accr ssed June 16 2020).

Araoz, R., Servent, D., Molgó, J., Iorga, B.I., Fruchart-Gail ard, C., Benoit, E., Gu, Z., Stivala, C., Zakarian, A., 2011. Total synthesis of pinnatoxins A ani $i$ and revision of the mode of action of pinnatoxin A. J. Am. Chem. Soc. 133, 10499-1n5Li https://doi.10.1021/ja201254c.

Arnich, N., Abadie, E., Delcourt, N., Fessard, V., Frem, I'A, Hort, V., Lagrange, E., Maignien, T., Molgó, J., Peyrat, M-B., Vernoux, J-P., Mattei. C., 20_0. Health risk assessment related to pinnatoxins in French shellfish. Toxicon 180, 1-1 J. 't' ' 'ss://doi.10.1016/j.toxicon.2020.03.007.

Arredondo, J., Nguyen, V.T., Chernyavsı." ..I., Bercovich, D., Orr-Urtreger, A., Kummer, W., Lips, K., Vetter, D.E., Grando, S.A., 2u? Central role of alpha7 nicotinic receptor in differentiation of the stratified squamo s epithelium. The Journal of Cell Biology 159(2), 325336. https://doi.10.1083/jcb.2002060 $九$

Barcia-Sardiñas, S., Caballero-Re, ,, , 2, 2017. Influencia del ENOS en el clima de la provincia de Cienfuegos. IX Congreso C. hano de Meteorología, 4-8 Diciembre de 2017, La Habana, Cuba. https://sometcuba.cubav. cu/congreso-meteorologia-2017/

Barcia, S., Fontes, M., R`míre.., M., Viera, E.Y., 2019. La sequía meteorológica 2014-2017, características e impartoc ... la provincia Cienfuegos. Rev. Cub. Met. 25, 319-333. http://opn.to/a/rSC7K.

Barcia-Sardiñas, S., Oı ^o-Martín, M., Hernández-González, D., Gómez-Díaz, D., GómezCamacho, L., 2020. Curnparación de diferentes índices bioclimáticos en Cuba. Rev. Cub. Met. 26, 2664-0880. http://opn.to/a/uaURQ.

BCM (Boletín Climático Mensual), 2015. Boletín Climático Mensual (Julio de 2015). Centro Meteorológico de Cienfuegos. INSMET. http://www.cmpcf.cu.

Berdalet, E., Fleming, L.E., Gowen, R., Davison, K., Hess, P., Backer, L.C., Moore, S.K., Hoagland, P., Enevoldsen, H., 2016. Marine harmful algal blooms, human health and wellbeing: challenges and opportunities in the 21st century. J. Mar. Biol. Assoc. UK. 96, 61-91. https://doi.10.1017/S0025315415001733.

Berdalet, E., Montresor, M., Reguera, B., 2017. Harmful algal blooms in fjords, coastal embayments, and stratified systems: recent progress and future research. Oceanography 30, 4657. https://www.jstor.org/stable/24897841.

Bourne, Y., Sulzenbacher, G., Radic, Z., Araoz, R., Reynaud, M., Benoit, E., Zakarian, A., Servent, D., Molgó, J., Taylor, P., Marchot, P., 2015. Marine Macrocyclic Imines, Pinnatoxins A and G: Structural Determinants and Functional Properties to Distinguish Neuronal $\alpha 7$ From 
Muscle $\alpha 1(2) \beta \gamma \delta$ nAChRs. Structure 23, 1106-15. https://doi.10.1016/j.str.2015.04.009.

Burkholder, J.M., Glibert, P.M., Skelton, H.M., 2008. Mixotrophy, a major mode of nutrition for harmful algal species in eutrophic waters. Harmful Algae 8, 77-93. https://doi.10.1016/j.hal.2008.08.010.

Chou, T., Haino, T., Kuramoto, M., Uemura, D., 1996. Isolation and structure of pinnatoxin D, a new shellfish poison from the Okinawan bivalve Pinna muricata. Tetrahedron Lett. 37, 402730. https://doi.10.1016/0040-4039(96)00753-8.

Cuddihy, S.L., Drake, S., Harwood, D.T., Selwood, A.I., McNabb, P.S., Hampton, M.B., 2016. The marine cytotoxin portimine is a potent and selective inducer of apoptosis. Apoptosis 21, 1447-1452. https://doi.10.1007/s10495-016-1302-x.

Darriba, D., Taboada, G.L., Doallo, R., Posada, D., 2012. jModelTest 2: more models, new heuristics and parallel computing. Nat. Methods 9, 772-772. https://doi.10.1038/nmeth.2109.

Delcourt, N., Lagrange, E., Abadie, E., Fessard, V., Frémy, J.-M., 'ernoux, J.-P., Peyrat, M.-B., Maignien, T., Arnich, N., Molgó, J., Mattei, C., 2019. Pinn+nx1..' deleterious effects on cholinergic networks: from experimental models to human he alth. Marine Drugs 17(7), 425. https://doi.10.3390/md17070425.

Díaz-Asencio, L., Vandersea, M., Chomérat, N., Frag^ s., clausing, R.J., Litaker, R.W., Chamero-Lago, D., Gomez-Batista, M., Moreira-Gonz ${ }^{1} \mathrm{a}$ Z, 4., Tester, P., Alonso-Hernandez, C., Dechraoui Bottein, M-Y., 2019. Morphology, tc icit! and molecular characterization of Gambierdiscus spp. towards risk assessment of ciguatra $\eta$ south central Cuba. Harmful Algae 86, 119-127. https://doi.10.1016/j.hal.2019.05.007.

Fleming LE, Kirkpatrick B, Backer J C, Nalsh CJ, Nierenberg K, Clark J, Reich, A., Hollenbeck, J., Benson, J., Cheng, Y.S., N. rr, J., Pierce, R., Bourdelais, A.J., Abraham, W.M., Kirkpatrick, G., Zaias, J., Wanner, As Mendes, E., Baden, D.G., 2011. Review of Florida red tide and human health ffects. Harmful Algae 10, 224-233. https://doi.10.1016/j.hal.2010.08.00 .

Garrett, M.J., Puchulutegui, C., \{.elv nod, A.I., Wolny, J.L., 2014. Identification of the harmful dinoflagellate Vulcanodinium $>$ ug $_{\text {, }}$ um recovered from a ballast tank of a globally traveled ship in Port Tampa Bar. Florida, USA. Harmful Algae 39, 202-209. https://doi.10.1016/j.hal.2014.0 014.

Geiger, M., Desanglois G., Hogeveen, K., Fessard, V., Lepretre, T., Mondeguer, F., Guitton, Y., Hervé, F., Séche،, V., F ovel, O., Pouchus, Y-F., Hess, P., 2013. Cytotoxicity, fractionation and dereplication of ex racts of the dinoflagellate Vulcanodinium rugosum, a producer of pinnatoxin G. Mar. Druss 11, 3350-71. https://doi.10.3390/md11093350.

Glibert, PM., Wilkerson, F.P., Dugdale, R.C., Raven, J.A., Dupont, C., Leavitt, P.R., Parker, A.E., Burkholder, J.M., Kana, T.M., 2016. Pluses and minuses of ammonium and nitrate uptake and assimilation by phytoplankton and implications for productivity and community composition, with emphasis on nitrogen-enriched conditions. Limnol. Oceanogr. 61, 165-197. https://doi.10.1002/lno.10203.

Grasshoff, K., Ehrhardt, M., Kremling, K., 1983. Methods of seawater analysis. Verlag Chemie, Weinheim, Germany.

Guindon, S., Dufayard, J.F., Lefort, V., Anisimova, M., Hordijk, W., Gascuel, O., 2010. New Algorithms and Methods to Estimate Maximum-Likelihood Phylogenies: Assessing the Performance of PhyML 3.0. Syst. Biol. 59, 307-21. https://doi.10.1093/sysbio/syq010.

Guiry, M.D., Guiry, G.M., 2020. AlgaeBase. World-wide electronic publication, National University of Ireland, Galway. http://www.algaebase.org. (Accessed 15 May 2020).

Hallegraeff, G.M., 2003. Harmful algal blooms: a global overview, in: Hallegraeff, G.M., 
Anderson, D.M., Cembella, A.D. (Eds.). Manual on Harmful Marine Microalgae UNESCO, Paris, pp. 25-49.

Hellyer, S.D., Indurthi, D., Balle, T., Runder-Varga, V., Selwood, A.I., Tyndall, J.D., Chebib, M., Rhodes, L., Kerr, D.S., 2015. Pinnatoxins E, F and G target multiple nicotinic receptor subtypes. J. Neurochem. 135, 479-91. https://doi.10.1111/jnc.13245.

Heisler, J., Glibert, P.M., Burkholder, J.M., Anderson, D.M., Cochlan, W., Dennison, W.C., Lewitus, A., Magnien, R., Marshal, G., Sellner, K., Stockwell, D.A., Stoecker, D.K., Suddleson, M., 2008. Eutrophication and harmful algal blooms: a scientific consensus. Harmful Algae 8, $3-$ 13. https://doi.10.1016/j.hal.2008.08.006.

Hernández-Becerril, D.U., Rodríguez-Palacio, M.C., Lozano-Ramíre,z C., 2013. Morphology and life stages of the potentially pinnatoxin-producing thecate dinoflagellate Vulcanodinium rugosum from the tropical Mexican Pacific. Bot. Mar. 56, 535-540. https://doi.10.1515/bot2013-0079.

Hess, P., Abadie, E., Hervé, F., Berteaux, T., Séchet, V., Aráoz, న . Molgó, J., Zakarian, A., Sibat, M., Rundberget, T., 2013. Pinnatoxin G is responsible or typical toxicity in mussels (Mytilus galloprovincialis) and clams (Venerupis decuss ${ }^{+} \rightarrow$ from Ingril, a French Mediterranean lagoon. Toxicon 75, 16-26. https://doi.10.101 j/j.te xicon.2013.05.001.

Katoh, K., Standley, D.M., 2013. MAFFT multiple seq. snce alignment software version 7: improvements in performance and usability. N. ll. Biol. Evol. 30, 772-80. https://doi.10.1093/molbev/mst010.

Kudela, R.M., Pitcher, G., Probyn, T., Figueiras, Г., Moita, T., Trainer, V., 2005. Harmful algal blooms in coastal upwelling s's' ${ }^{\prime} \cdot \mathrm{ns}$ Oceanography 18, 184-197. https://doi.org/10.5670/oceanog.2005.53.

Lassus, P., Chomérat, N., Hess, P., Nézaı. E , 2016. Toxic and harmful microalgae of the World Ocean-micro-algues toxiques et nuisibles ¿- l'océan mondial. IOC manuals and guides 68 (English/French). ISSHA, Copenhagen.

Lin, C.J., Wade, T.J., Sams, E.A. J s ur, A.P., Chapman, A.D., Hilborn, E.D., 2015. A prospective study of marine phyt ${ }^{1} a_{1}{ }^{1}$ on and reported illness among recreational beachgoers in Puerto Rico, 2009. Environ. Fi alth Perspect. 124, 477-483. https://doi.10.1289/ehp.1409558.

Mafra, L.L.Jr., Nagai, S., Uchia. H., Tavares, C.P.S., Escobar, B.P., Suzuki, T., 2016. Harmful effects of Dinophysis to the cilı te Mesodinium rubrum: Implications for prey capture. Harmful Algae 59, 82-90. https://N-i $12.1016 /$ j.hal.2016.09.009.

McCarron, P., Rourn $V^{r} \Delta$., Hardstaff, W., Pooley, B., Quilliam, M.A., 2012. Identification of pinnatoxins and discove $y$ of their fatty acid ester metabolites in mussels (Mytilus edulis) from eastern Canada. J. Agrı. Food Chem. 60, 1437-46. https://doi.10.1021/jf204824s.

Molgó J, Benoit E, Aráoz R, Zakarian A, Iorga BI., 2016. Spirolides and Cyclic Imines: Toxicological Profile, in: Gopalakrishnakone, P., Haddad, Jr V., Tubaro, A., Kim, E., Kem, W.R. (Eds.). Marine and Freshwater Toxins. Springer, Dordrecht, Netherlands, pp. 193-217.

Moore, R.E., Ohtani, I., Moore, B.S., Koning, C.B., Yoshida, W.Y., Runnegar, M.T.C., Carmichael, W.W., 1993. Cyanobacterial toxins. Gaz. Chim. Ital. 123, 29-36.

Moreira-González, A.R., Comas, A., Valle, A., Seisdedo, M., Fernandes, L.F., 2016. Bloom of Vulcanodinium rugosum linked to skin lesions in Cienfuegos Bay, Cuba. HAN 55, 10-11. http://www.e-pages.dk/ku/1259/.

Moreira-González, A.R., Seisdedo-Losa, M., Muñoz-Caravaca, A., Comas-González, A., Alonso-Hernández, C., 2014. Spatial and temporal distribution of phytoplankton as indicator of eutrophication status in the Cienfuegos Bay, Cuba. RGCI 14, 597-609. https://doi.10.5894/rgci506.

Morera-Gómez, Y., Alonso-Hernández, C.M., Santamaría, J.M., Elustondo, D., Lasheras, E., 
Widory, D., 2019. Levels, spatial distribution, risk assessment, and sources of environmental contamination vectored by road dust in Cienfuegos (Cuba) revealed by chemical and $\mathrm{C}$ and $\mathrm{N}$ stable isotope compositions. Environ. Sci. Pollut. R. 1-13. https://doi.10.1007/s11356-01906783-7.

Morera-Gómez, Y., Elustondo, D., Lasheras, E., Alonso-Hernández, C. M., \& Santamaría, J. M., 2018. Chemical characterization of PM10 samples collected simultaneously at a rural and an urban site in the Caribbean coast: Local and long-range source apportionment. Atmos. Environ. 192, 182-192. https://doi.org/10.1016/j.atmosenv.2018.08.058.

Munday, R., Selwood, A.I., Rhodes, L., 2012. Acute toxicity of pinnatoxins E, F and G to mice. Toxicon 60, 995-9. https://doi.10.1016/j.toxicon.2012.07.002.

Muñoz-Caravaca, A., Doulliet, P., Díaz-García, O., Fichez, R., Herrera, R.H., Alcántara-Carrió, J., García-Rodriguez, A., 2012. Flushing time in the Cienfuegos Bay. Nat. Resour. Model. 25, 434-455. https://doi.10.1111/j.1939-7445.2012.00126.x.

NEPC (National Environment Protection Council), 1999. In: Chapı - 3. The aqueous chemistry of cyanide and nitrogen. Available at <Thesis.lib unls elb.edu.au/adtroot/uploads/ approved/adtVU2002.0068/public/05_ch3.pdf>, pp. 65-75.

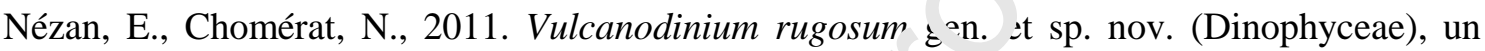
nouveau dinoflagellé' marin de la côte méditerranéenne f. nçaise. Cryptogam. Algol. 32, 3-18, https://doi.10.7872/crya.v32.iss1.2011.003.

Nézan, E., Tillmann, U., Bilien, G.1., Boulben, S., Chère, ‘., Zentz, F., Salas, R., Chomérat, N., 2012. Taxonomic revision of the dinoflagellate in iphidoma caudata: Transfer to the genus Azadinium (Dinophyceae) and proposal of two vi "ati s, based on morphological and molecular phylogenetic analyses. J. Phycol. 48, 925-929. . ttps://doi.10.1111/j.1529-8817.2012.01159.x.

Norris, D.A., Middleton, M.H., Whang, '` ‘ ‘chleicher, M., McGovern, T., Bennion, S.D. et al., 1997. Human keratinocytes maintain rever hle antiapoptotic defenses in vivo and in vitro. Apoptosis 2(2), 136-148. https://doi.1v. ${ }^{1023 / A: 1026456229688 . ~}$

Onuma, Y., Satake, M., Ukena, T., ' o ı s , J., Chanteau, S., Rasolofonirina, N., Ratsimaloto, M., Naoki, H., Yasumoto, T., 19 ${ }^{\circ}$, Intification of putative palytoxin as the cause of clupeotoxism. Toxicon 37, 55-6: https://doi.10.1016/s0041-0101(98)00133-0.

Osborne, N.J., Shaw, G.P., T008. Dermatitis associated with exposure to a marine cyanobacterium during rec eational water exposure. BMC Dermatol. 8, 5. https://doi.10.1186/1471 E94; 'j-5.

Pierce, R.H., Henry, M.. 2008 . Harmful algal toxins of the Florida red tide (Karenia brevis): natural chemical stresso $;$ in South Florida coastal ecosystems. Ecotoxicology 17(7), 623-631. https://doi.10.1007/s16u+6-008-0241-x

Rambla-Alegre, M., Miles, C.O., de la Iglesia, P., Fernández-Tejedor, M., Jacobs, S., Sioen, I., Verbeke, W., Samdal, I.A., Sandvik, M., Barbosa, V., Tediosi, A., Madorran, E., Granby, K., Kotterman, M., Calis, T., Diogene, J., 2018. Occurrence of cyclic imines in European commercial seafood and consumers risk assessment. Environ. Res. 161, 392-398. https://doi.10.1016/j.envres.2017.11.028.

Ramos, V., Vasconcelos, V., 2010. Palytoxin and analogs: biological and ecological effects. Mar. Drugs 8, 2021-37. https://doi.10.3390/md8072021.

Randall, J.E., 2005. Review of clupeotoxism, an often fatal illness from the consumption of clupeoid fishes. Pac. Sci. 59, 73-77. https://doi.10.1353/psc.2005.0013.

Rhodes, L., Smith, K., Selwood, A., McNabb, P., van Ginkel, R., Holland, P., Munday, R., 2010. Production of pinnatoxins by a peridinoid dinoflagellate isolated from Northland, New Zealand. Harmful Algae 9, 384-389. https://doi.10.1080/00288330.2011.586041.

Rhodes, L., Smith, K., Selwood, A., McNabb, P., Munday, R., Suda, S., Molenaar, S., 
Hallegraeff, G., 2011a. Dinoflagellate Vulcanodinium rugosum identified as the causative organism of pinnatoxins in Australia, New Zealand and Japan. Phycologia 50, 624-628. https://doi.org/10.2216/11-19.1.

Rhodes, L., Smith, K., Selwood, A., McNabb, P., Molenaar, S., Munday, R., Wilkinson, C., Hallegraeff, G., 2011b. Production of pinnatoxins E, F and G by scrippsielloid dinoflagellates isolated from Franklin Harbour, South Australia. N. Z. J. Mar. Freshwater Res. 45, 703-709. https://doi.10.1080/00288330.2011.586041.

Ronquist, F., Huelsenbeck, J.P., 2003. MrBayes 3: Bayesian phylogenetic inference under mixed models. Bioinformatics 19, 1572-1574. https://doi.10.1093/bioinformatics/btg180.

Rundberget, T., Aasen, J.A.B., Selwood, A.I., Miles, C.O., 2011. Pinnatoxins and spirolides in Norwegian blue mussels and seawater. Toxicon 58, 700-711. https://doi.10.1016/j.toxicon.2011.08.008.

Seisdedo, S., Moreira, A.R., Arencibia, G., 2012. Características físico-químicas de las aguas y del fitoplancton en zonas de baño de la Bahía de Cienfuegos, Cuba (?008-2009). Rev. Inv. Pesq. 29, 38-43. https://www.oceandocs.org/handle/1834/9797.

Selwood, A.I., Miles, C.O., Wilkins, A.L., van Ginkel, R., 'rn ^uay, R., Rise, F., McNabb, P., 2010. Isolation, Structural Determination and Acute Toxicit, of 'innatoxins E, F and G. J Agr. Food Chem. 58, 6532-42. https://doi.10.1021/jf100267a.

Selwood, A.I., Wilkins, A.L., Munday, R., Shi, r, R ıodes, L.L., Holland, P.T., 2013. Portimine: a bioactive metabolite from the benthic di. fflagellate Vulcanodinium rugosum. Tetrahedron Lett. 54, 4705-4707. https://doi.10.1\% .1/1.tetlet.2013.06.098.

Selwood, A.I., Wilkins, A.L., Munday, R., Gu. H.. smith, K.F., Rhodes, L.L., Rise, F., 2014. Pinnatoxin H: a new pinnatoxin analoge _ $\therefore$ on a South China Sea Vulcanodinium rugosum isolate. Tetrahedron Lett. 55, 5508-10. hus ss' 'doi.10.1016/j.tetlet.2014.08.056.

Smith, K.F., Rhodes, L.L., Suda, S., Selwood, A.I., 2011. A dinoflagellate producer of pinnatoxin G, isolated from sub-trnpı al Japanese waters. Harmful Algae 10, 702-705. https://doi.10.1016/j.hal.2011.05.00 .

Sosa, S., Pelin, M., Cavion, F., Her'é, F., Hess, P., Tubaro, A., 2020. Acute oral toxicity of pinnatoxin G in mice. Toxins, 2(¿, 87. https://doi.10.3390/toxins12020087.

Spergel, J.M., Mizoguchi, E., Otitgen, H., Bhan, A.K., Geha, R.S., 1999. Roles of TH1 and TH2 cytokines in a murin m'del of allergic dermatitis. J Clin Invest. 103(8), 1103-1111. https://doi. 10.1172/JCI',66,

Takada, N., Umemura, V., suenaga, K., Chou, T., Nagatsu, A., Haino, T., Yamada, K., Uemura, D., 2001. Pinnatoxins B and C, the most toxic components in the pinnatoxin series from the Okinawan bivalve Pinna muricata. Tetrahedron Lett. 42, 3491-3494. https://doi.10.1016/S00404039(01)00480-4.

Tartaglione, L., Dell'Aversano, C., Mazzeo, A., Forino, M., Wieringa, A., Ciminiello, P., 2016. Determination of Palytoxins in Soft Coral and Seawater from a Home Aquarium. Comparison between Palythoa- and Ostreopsis-Related Inhalatory Poisonings. Environ. Sci. Technol. 50, 1023-1030. https://doi.10.1021/acs.est.5b05469.

Tomas, C.R., (Ed) 1997. Identifying marine phytoplankton. Academic Press, San Diego, 429 California.

Tubaro, A., Durando, P., Del Favero, G., Ansaldi, F., Icardi, G., Deeds, J.R., Sosa, S., 2011. Case definitions for human poisonings postulated to palytoxins exposure. Toxicon 57, 478-495. https://doi.10.1016/j.toxicon.2011.01.005.

Uemura, D., Chou, T., Haino, T., Nagatsu, A., Fukuzawa, S., Zheng, S.Z., Chen, H., 1995. Pinnatoxin-a a Toxic Amphoteric Macrocycle from the Okinawan Bivalve Pinna muricata. J. Am. Chem. Soc. 117, 1155-1156. https://doi.10.1021/ja00108a043. 
UNEP (United Nations Environment Programme), 1988. Standard chemical methods for marine environmental monitoring. Nairobi, Kenya, United Nations Environment Programme.

Vila, M., Abós-Herràndiz, R., Isern-Fontanet, J., Àlvarez, J., Berdalet, E., 2016. Establishing the link between Ostreopsis cf. ovata blooms and human health impacts using ecology and epidemiology. Sci. Mar. 80, 107-115. https://doi.10.3989/scimar.04395.08A.

Vila, M., Garcés, E., Masó, M., Camp, J., 2001. Is the distribution of the toxic dinoflagellate Alexandrium catenella expanding along the NW Mediterranean coast? Mar. Ecol. Prog. Ser. 222, 73-83. https://doi.10.3354/meps222073.

Walsh, J.J., Steidinger, K.A., 2001. Saharan dust and Florida red tides: the cyanophyte connection. J. Geophys. Res-Oceans. 106, 11597-11612. https://doi.10.1029/1999JC000123.

Wells, M.L., Trainer, V.L., Smayda, T.J., Karlson, B.S., Trick, C.G., Kudela, R.M., Ishikawa, A., Bernard, S., Wulff, A., Anderson, D.M., Cochlan, W.P., 2015. Harmful algal blooms and climate change: Learning from the past and present to forecast he future. Harmful Algae 49, 68-93. https:// doi.10.1016/j.hal.2015.07.009.

Zeng, N., Gu, H., Smith, K.F., Rhodes, L.L., Selwood, A.I., Ya 1 g, $\backslash^{\top}$., 2012. The first report of Vulcanodinium rugosum (Dinophyceae) from the South $\mathrm{C}^{\prime}{ }^{\prime}$ in' sea with a focus on the life cycle. N. Z. J. Mar. Freshwater Res. 46, 511-521. https://dni. '0.1' 80/00288330.2012.719911.

Table 1. LC-MS/MS parameters.

\begin{tabular}{|c|c|c|c|c|c|}
\hline Toxins & Transitions (Q1>Q3) & $\overline{\mathrm{D}^{\top}} \overline{(\mathrm{I})}$ & $\mathrm{EP}(\mathrm{V})$ & $\mathrm{CE}(\mathrm{eV})$ & $\mathrm{EP}(\mathrm{V})$ \\
\hline PnTX-G & $694.4>658.4,458.3,164.1^{a}$ & 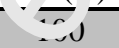 & 10 & $53,58,69$ & $10,12,8$ \\
\hline PnTX-A & $712.4>676.4,458.3,16^{\prime}{ }^{a}$ & 100 & 10 & $53,58,69$ & $10,12,8$ \\
\hline PnTX-B/C & $741.4>668.0,458.3, ?, 4.1$ & 100 & 10 & $53,58,69$ & $10,12,8$ \\
\hline PnTX-D & $782.4>746.4,488.3,164$. & 100 & 10 & $53,58,69$ & $10,12,8$ \\
\hline PnTX-E & $784.4>748.4,488{ }^{2} .164 .1$ & 100 & 10 & $53,58,69$ & $10,12,8$ \\
\hline PnTX F & $766.4>730.4,488.3,1^{-} 4.1^{a}$ & 100 & 10 & $53,58,69$ & $10,12,8$ \\
\hline Pteriatoxins $(\mathrm{a}, \mathrm{b}, \mathrm{c})$ & $831.5>787.5,45, .3{ }^{1} 64.1^{a}$ & 100 & 10 & $53,58,69$ & $10,12,8$ \\
\hline Portimine & $402.5>246.0,134 ., 148.1^{a}$ & 100 & 10 & $47,47,47$ & $12,12,12$ \\
\hline
\end{tabular}

Note: ${ }^{a}$ quantitative transition; $\mathrm{DF}^{\mathrm{F}}$ : de.' ustering potential; CE: collision energy; EP: exit potential

Table 2. Demographic inu acteristics of cases $(n=60)$ reporting skin irritation during the Vulcanodinium rugosum bloom in Cienfuegos Bay.

\begin{tabular}{lc}
\hline Characteristic & $\mathrm{n}(\%)$ \\
\hline Sex & \\
Male & $49(81.6)$ \\
Female & $11(18.3)$ \\
Age (Years) & \\
$0-4$ & $5(9.0)$ \\
$5-9$ & $5(9.0)$ \\
$10-14$ & $37(61.2)$ \\
$15-19$ & $7(10.9)$ \\
$20-39$ & $6(9.9)$ \\
$40-64$ & - \\
$\geq 65$ & - \\
Ethnicity & - \\
Non-Hispanic & - \\
Hispanic & $60(100)$ \\
\hline
\end{tabular}


Table 3. Mean cell density $\pm \mathrm{SD}$ of Vulcanodinium rugosum and other co-occurring phytoplankton taxa for samples taken at early, mid- and late bloom stages in two neighbor beaches in Cienfuegos Bay, Cuba. Maximum cell densities for each species are shown between brackets.

\begin{tabular}{ll}
\hline Taxa & Abundance $($ cells L \\
\end{tabular}

Table 4. List of toxic compounds and their intracellula. concentrations found in a plankton sample during the Vulcanodinium rugosum bloom, w1 ${ }^{h}$ tre $^{2}$ theoretical and observed $\mathrm{m} / \mathrm{z}$, and resulting $\square$ ppm values.

\begin{tabular}{|c|c|c|c|c|c|}
\hline Toxins & $\begin{array}{l}\text { Concentration } \\
\left(\text { fg cell }^{-1}\right)\end{array}$ & $\overline{\text { Ions spf }-16}$ & $\begin{array}{c}\text { Theoretical } \\
\mathrm{m} / \mathrm{z}\end{array}$ & $\begin{array}{c}\text { Observed }^{\mathrm{a}} \\
\mathrm{m} / \mathrm{z}\end{array}$ & $\mathrm{ppm}$ \\
\hline PnTX-D & 3.1 & {$[\mathrm{M}+\mathrm{H}]^{+}$} & 782.4838 & - & - \\
\hline PnTX-E & 94.2 & $\left\lceil\mathrm{M}+\mathrm{I}^{+}\right.$ & 784.4994 & 784.5022 & 3.5 \\
\hline $\begin{array}{l}\text { PnTX-E } \\
\text { isomer }\end{array}$ & 4.2 & {$[\mathrm{~N} 1+\mathrm{i}]^{+}$} & 784.4994 & 784.5009 & 1.9 \\
\hline PnTX-F & 441.8 & {$[\mathrm{M}+\mathrm{H}]^{+}$} & 766.4889 & 766.4919 & 4.0 \\
\hline $\begin{array}{l}\text { PnTX-F } \\
\text { isomer }\end{array}$ & 34.2 & {$[\mathrm{M}+\mathrm{H}]^{+}$} & 766.4889 & 766.4919 & 4.0 \\
\hline PnTX-G & C.1 & {$[\mathrm{M}+\mathrm{H}]^{+}$} & 694.4677 & - & - \\
\hline Portimine & $\therefore 50$. & {$[\mathrm{M}+\mathrm{H}]^{+}$} & 402.2275 & 402.2285 & 2.5 \\
\hline
\end{tabular}

${ }^{\mathrm{a}}$ based on the monoisotopic mass 


\section{Figure captions}

Figure 1. Map of Cienfuegos Bay, Cuba, showing the location where the Vulcanodinium rugosum bloom occurred.

Figure 2. Bloom of Vulcanodinium rugosum in Cienfuegos Bay, Cuba, during July-August 2015. A. General view of the bloom along $\sim 0.7 \mathrm{Km}$ of coastline; the inset (lower right) highlights resting cysts and a motile cell of $V$. rugosum, as viewed by light microscopy, Scale bar $=10 \mu \mathrm{m}$. B. Water discoloration due to the bloom in the most affected area, "El Círculo Juvenil" Beach.

Figure 3. Vulcanodinium rugosum. A-B. Light microscopy ima res \& $f$ a fixed cell (A), a motile cell and resting cysts (B). C-D. Scanning electron microsr $o_{r}:$ ir . ages detailing the thecal plate pattern in ventral (C) and dorsal (D) view. Scale bar $=0 \mu_{\text {s }}$

Figure 4. Maximum Likelihood phylogenetic tree iníerred irom ITS-5.8S rDNA sequences of various sequences of Vulcanodinium rugosum ana uther related dinoflagellates. Prorocentrum elegans is used as an outgroup. Sequence " $\mathrm{m}$ the Cienfuegos Bay bloom isolate is shown with boldface and gray background. Likelihu $d$ value: $\log l \mathrm{k}=-4049.9$. Ti/Tv for purines: 8.37 ; Ti/Tv for pyrimidines: 0.22 . Assumed nucle ti le frequencies: $f(A)=0.18320, f(C)=0.27636, f(G)=$ $0.24831, f(T)=0.29212$. G^ $\mathrm{nm}_{\mathfrak{a}}$ shape parameter: 1.456 ; proportion of invariant: 0.249 . Numbers at nodes represu t brotstrap support values from Maximum Likelihood (ML) and posterior probabiliti - fi $` m^{\prime}$ ', ayesian Inference (BI).

Figure 5. LC-MS/MS -iromatogram showing the toxin profile of a natural plankton sample during the Vulcanodinium rugosum bloom. PnTX: pinnatoxin. PnTX-E and PnTX-F are indicated with an arrow, and second peaks are their isomers. 


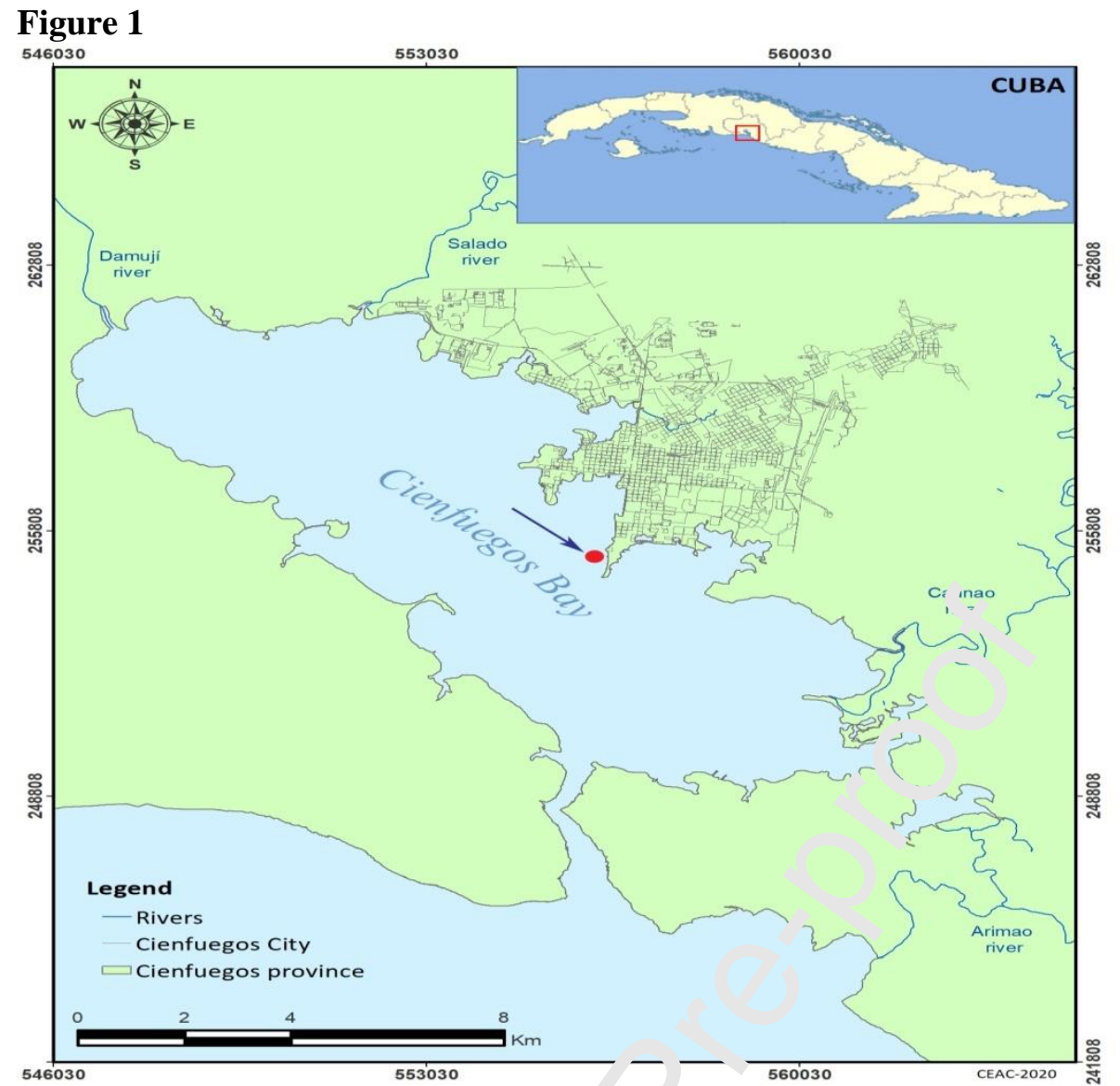

Figure 2

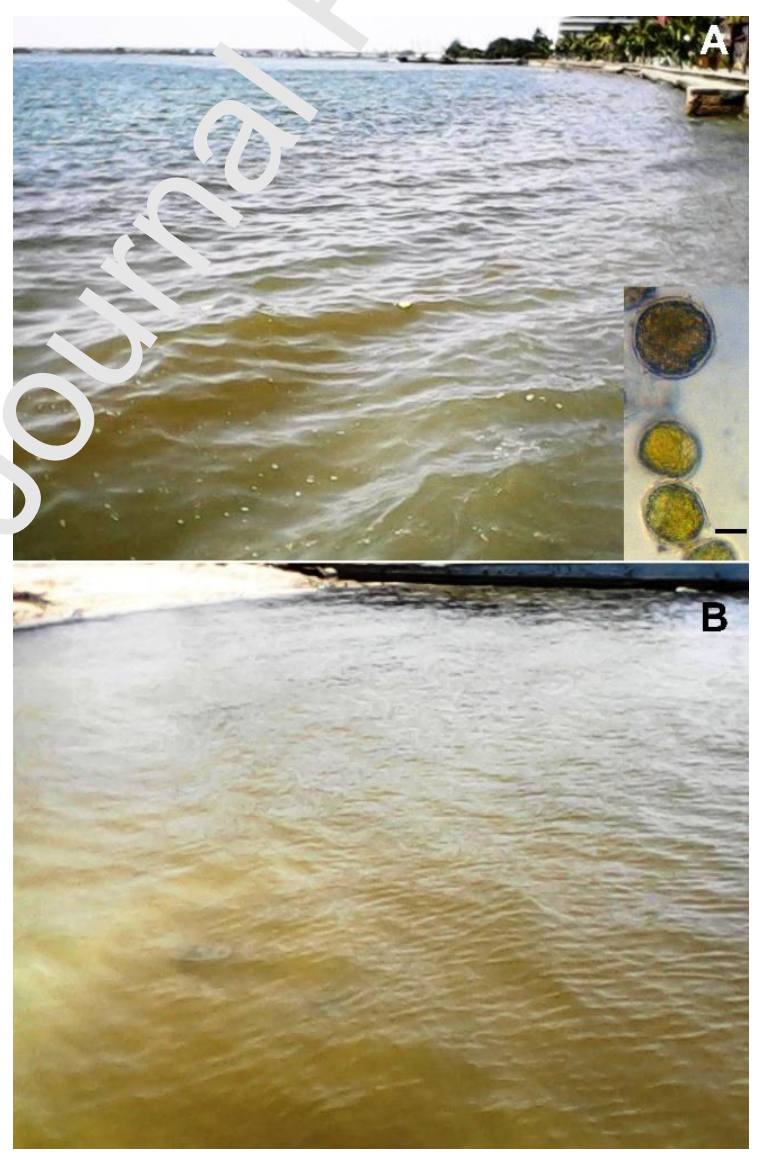


Figure 3

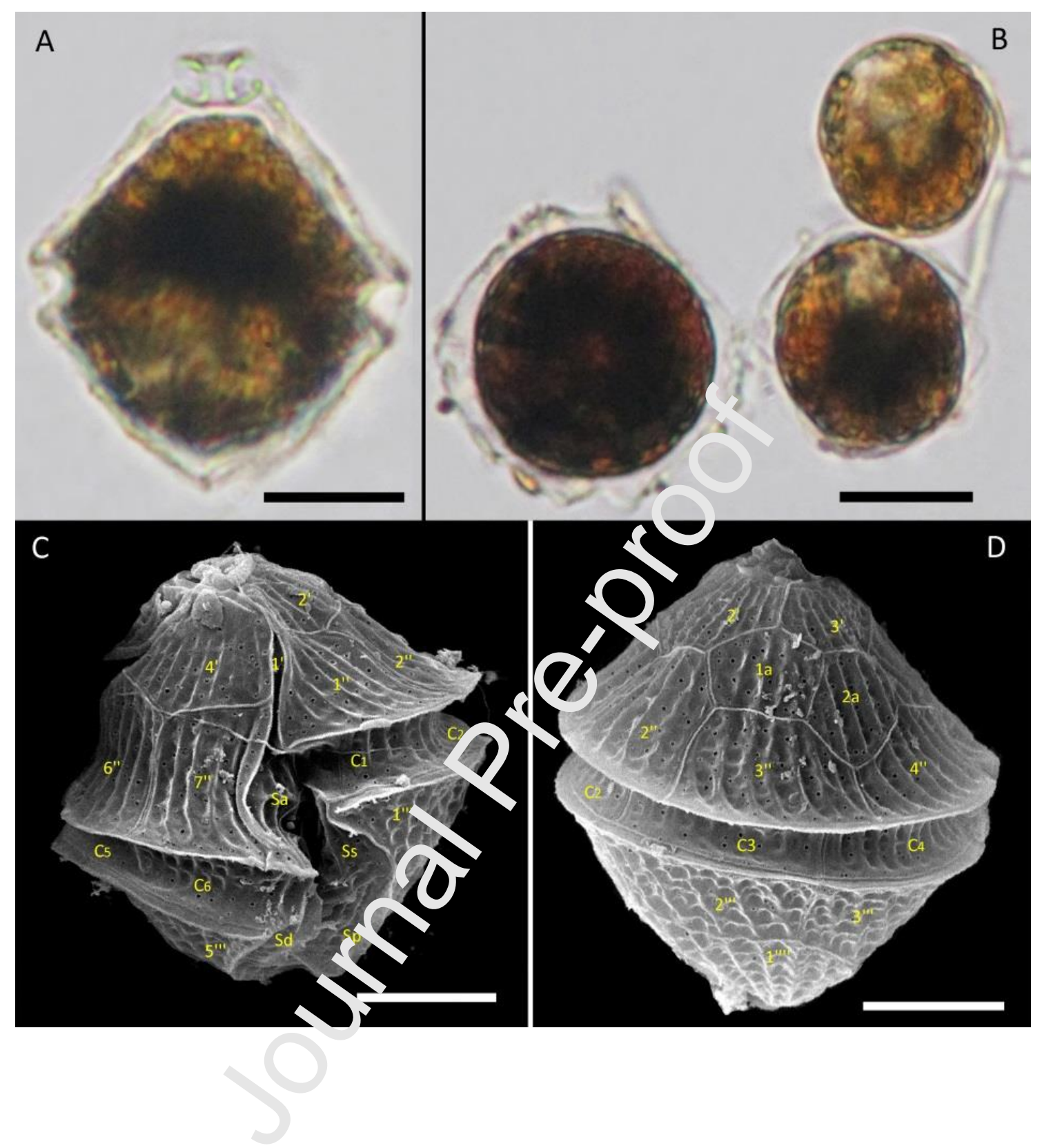




\section{Figure 4}

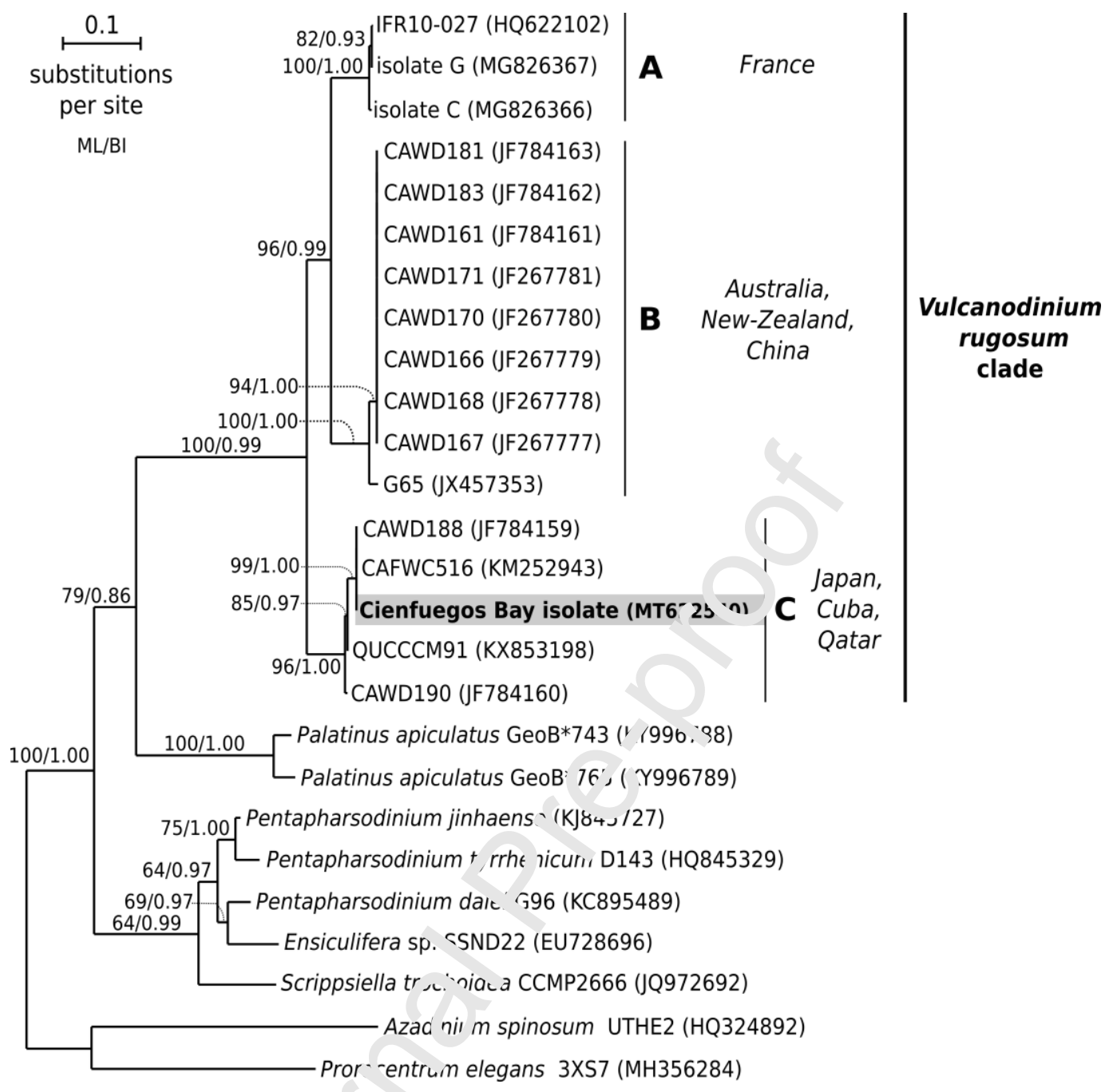


Figure 5

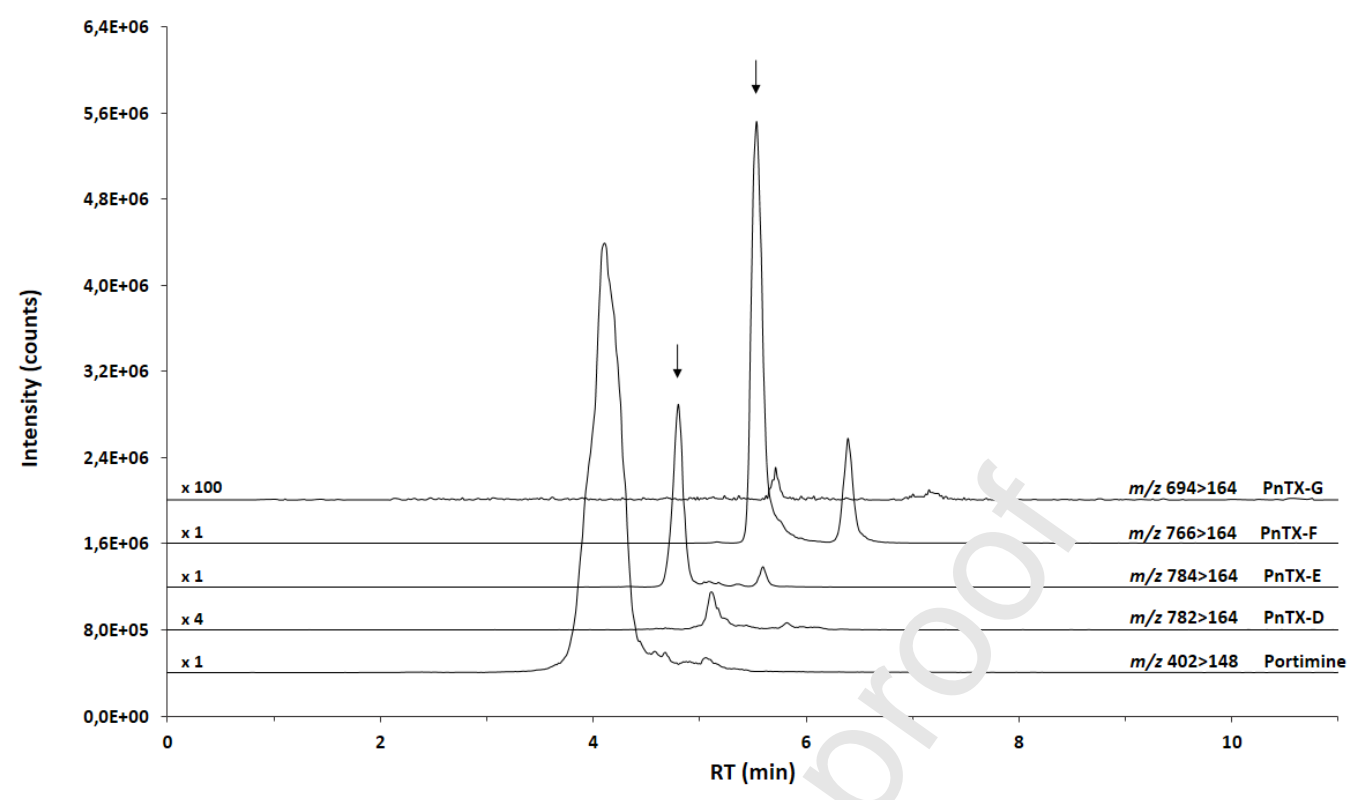




\section{Declaration of competing interests}

$\bigotimes$ The authors declare that they have no known competing financial interests or personal relationships that could have appeared to influence the work reported in this paper.

$\square$ The authors declare the following financial interests/personal relationships which may be considered as potential competing interests:

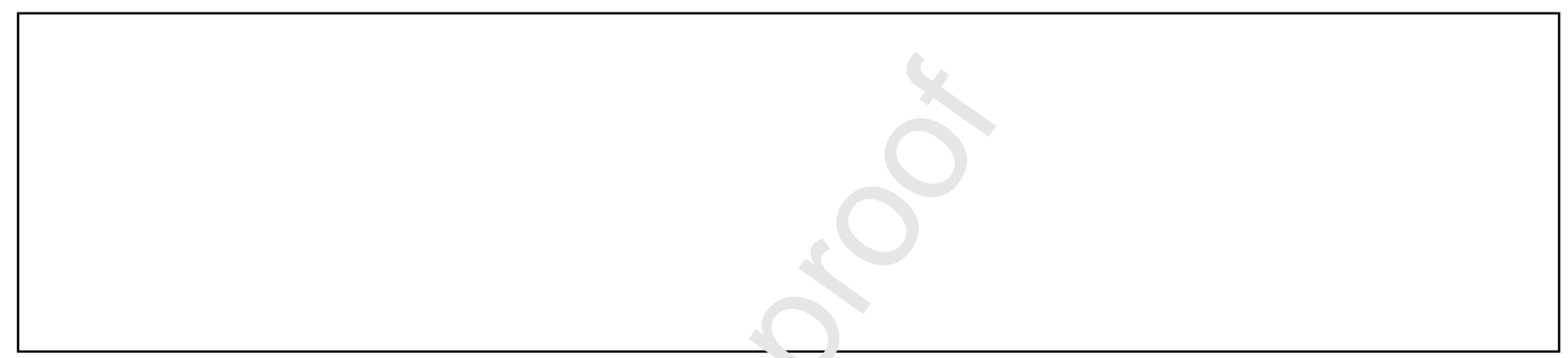




\section{Author Contributions Statement}

A.R.M.-G.: Conceptualization, Investigation, Formal analysis, Writing - original draft; A.C.-G.: Investigation; A.V.-P.: Investigation; M.S.-L.: Investigation; O.H.-L.: Investigation, L.F.F.: Investigation, Writing - review \& editing; N.C.: Data curation, Formal analysis, Resources, Writing - review \& editing; G.B.: Investigation; F.H.: Investigation, Writing - review \& editing; G.A.R.: Investigation; P.H.: Resources, Supervision, Writing - review \& editing; C.M.A.-H.: Conceptualization, Funding acquisition, Project administration, Supervision, Writing - review \& editing; L.L.M.Jr.: Conceptualization, Funding acquisition, Resources, Supervision, Writing - review \& editing. 


\section{Graphical abstract}
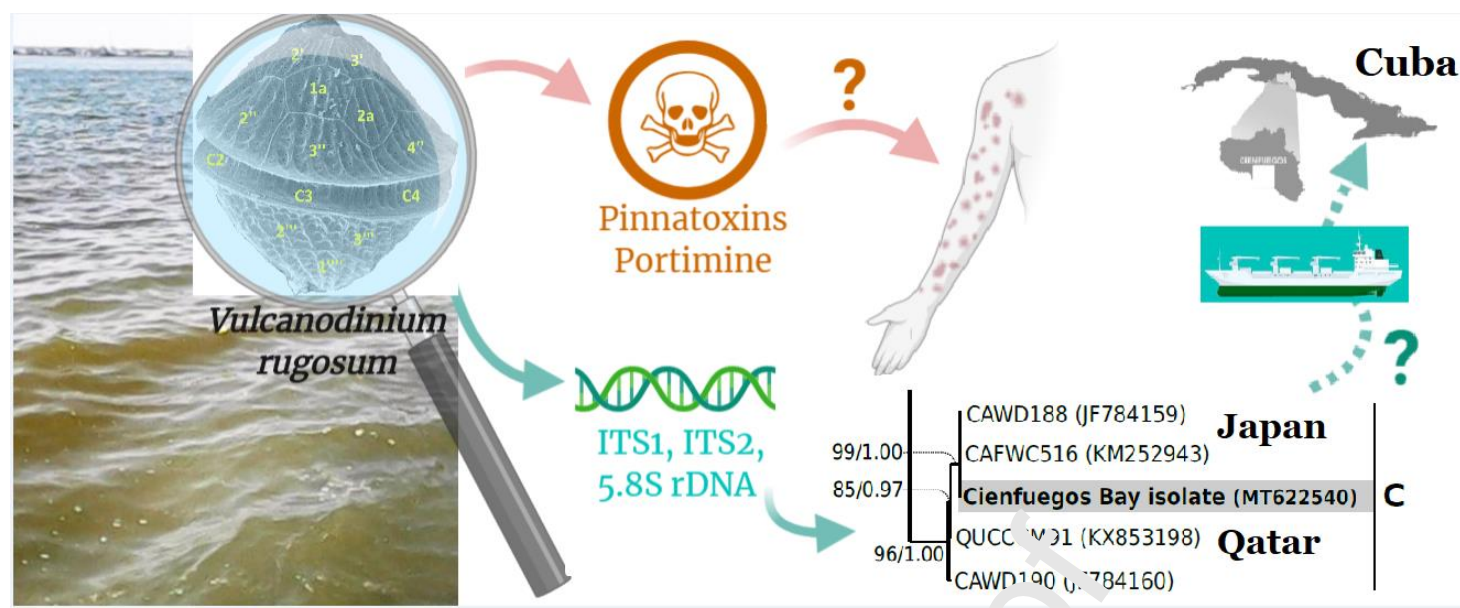


\section{Highlights}

- First report of a Vulcanodinium rugosum bloom affecting human health

- Sixty people, mostly children, developed acute skin irritation upon direct exposure

- Bloom contained pinnatoxins and portimine, potential causative factors of dermatitis

- Phylogenetics suggest recent introduction from the Pacific Ocean via ballast water

- Bloom associated with unusual droughts and ex epi onally high temperatures 